\title{
Rodrigo's Eleventh Chronicle: Empathy and False Empathy
}

\author{
Richard Delgado $†$
}

\author{
INTRODUCTION: RODRIGO RETURNS AND ACCOUNTS \\ FOR HIS RECENT ACTIVITIES
}

I was sitting in my darkened office one afternoon, thinking about life. To tell the truth, I was missing Rodrigo. ${ }^{1}$ Not long ago, I had consigned him to the Great Beyond. ${ }^{2}$ But now, I was flooded with regret and sadness. I missed his brashness, his insouciant originahty. Odd, I had not thought of myself as sentimental. How could I have allowed him to succumb to the

Copyright @ 1996 California Law Review, Inc.

$\dagger$ Charles Inglis Thomson Professor of Law, University of Colorado; J.D., Boalt Hall School of Law, University of California, Berkeley, 1974.

1. See Richard Delgado, Rodrigo's Chronicle, 101 Y ALE L.J. 1357 (1992) (review essay), [hereinafter Delgado, Chronicle], introducing Rodrigo Crenshaw, my fictional alter ego and the halfbrother of famed civil rights lawyer Geneva Crensbaw. See Derrick Beld, ANd We Are Not Saved: THE Elusive Quest for Racial Justice (1987) (on Geneva). The son of an African American serviceman and an Italian mother, Rodrigo moved to Italy when his father was assigned to a U.S. outpost there. After he graduated from the base high school, Rodrigo attended Bologna University where he eamed a law degree and graduated second in his class. Rodrigo's Chronicle opens when the young law graduate seeks out "the professor" (his fictional mentor and intellectual foil) for career advice. Despite their age difference, the two become good friends, discussing in a series of meetings over the following two years nationalism and Critical Race Theory (Delgado, Chronicle, supra); the economic free market and race (Richard Delgado, Rodrigo's Second Chronicle: The Economics and Politics of Race, 91 Mrch. L. Rev. 1183 (1993) (hook review) [hereinafter Delgado, Second Chronicle]); love and civil rights (Rodrigo's Third Chronicle: Care, Competition, and the Redemptive Tragedy of Race, 81 CALIF. L. REv. 387 (1993) (review dialogue) [hereinafter Delgado, Third Chronicle]); legal rules and culture (Richard Delgado, Rodrigo's Fourth Chronicle: Neutrality and Stasis in Antidiscrimination Law, 45 Stan. L. Rev. 1133 (1993) (review essay) [hereinafter Delgado, Fourth Chronicle]); the neorepublican revival (Richard Delgado, Rodrigo's Fifth Chronicle: Civitas, Civil Wrongs, and the Politics of Denial, 45 StAN. L. Rev. 1581 (1993)); the relation of black men and black women (Richard Delgado, Rodrigo's Sixth Chronicle: Intersections, Essences, and the Dilemma of Social Reform, 68 N.Y.U. L. REv. 639 (1993) [hereinafter Delgado, Sixth Chronicle]); the theory of the state (Richard Delgado, Rodrigo's Seventh Chronicle: Race, Democracy, and the State, 41 UCLA L. REv. 721 (1994)); black and white crime (Richard Delgado, Rodrigo's Eighth Chronicle: Black Crime, White Fears-On the Social Construction of Threat, 80 VA. L. REv. 503 (1994) [hereinafter Delgado, Eighth Chronicle)); pragmatism and civil rights (Richard Delgado, Rodrigo's Ninth Chronicle: Race, Legal Instrumentalism, and the Rule of Law, 143 U. PA. L. REv. 379 (1994) [hereinafter Delgado, Ninth Chronicle]); and merit and race (Richard Delgado, Rodrigo's Tenth Chronicle: Merit and Affirmative Action, 83 Gro. L.J. 1711 (1995) [hereinafter Delgado, Tenth Chronicle]).

2. See Richard Delgado, Rodrigo's Final Chronicle: Cultural Power, the Law Reviews, and the Attack on Narrative Jurisprudence, 68 S. CAL. L. REv. 545, $574-75$ (1995) (discussing Rodrigo's disappearance after his struggle to justify narrative legal discourse). 
critique of narrativity in Rodrigo's Final Chronicle? ${ }^{3}$ I had gotten a great series of articles out of our ineetings. ${ }^{4}$ He had pushed and challenged my thinking, and helped dispel solne of the loneliness I've felt in this sometiines desolate job. And now, he was gone.

I was just getting ready to turn on the light and resume reading the pile of seininar papers that had awaited me smce my return from the AALS, when I heard a shuffling sound outside my door. A brown envelope materialized on my carpet, pushed through the crack by someone whose footsteps I now heard disappearing down the hall. "I'In here," I shouted.

"Oh, I didn't see your light," a familiar voice said.

I turned on the switch and opened the door. "Rodrigo!" I exclaimed. "I was just thinking about you. What are you doing here?"

"We last parted rather suddenly," Rodrigo explained, "so I brought you a note explaining what happened to me after that incident at the AALS. I didn't want it to be too much of a shock. I also brought you a book-a magazine, actually."

"Come on in. What on earth happened to you? I was afraid I would never see you again."

Rodrigo picked up the envelope froin the floor, laid it on the corner of my desk, and glanced around iny offlce. "Do you have a ininute?" He gestured toward the pile of neatly typed student papers in the center of my desk. "It looks like you're busy."

"Quite the contrary," I assured him. "These grades aren't due for another week. I'm eager to hear what happened to you. And, before you begin, can I offer you solne coffee?"

My young friend nodded enthusiastically, and sat down in the one chair in my office not presently used as a bookshelf or table. As I busied inyself ineasuring the water and grounds for iny new office coffee maker (a sleek European model), Rodrigo began. out?"

"Do you remember, Professor, where we were when the lights went

"Yes, we had been talking, rather late at might as I remember, in that basement dive in the giant AALS hotel. We were discussing the critique of narrativity and legal storytelling, in particular that section ineeting where

3. Id. at $\mathbf{5 7 4}$ (describing how Rodrigo self-deconstructs in the face of the formalist attack on narrative jurisprudence). "Like all storytelling, had [Rodrigo] and his lessons been lost in a cloud of abstraction, in which learned commentators paid endless attention to the form, the quality, the procedure of storytelling, and gradually lost sight of the content of the stories themselves?" Id. Happily, my concern that Rodrigo's voice had been silenced was greatly exaggerated. See infra notes 5-10 and accompanying text.

4. See supra notes 1-2 (describing previous Chronicles); see also Richard DetaAdo, The Rodrigo Chronicles: Conversations About America and Race (1995).

5. The magazine, as I leamed later, was RACE TratroR, edited by Noel Ignatiev and John Garvey. The package also contained Treason to Whiteness Is Loyalty to Humanity: An Interview with Noel Ignatiev of Race Traitor Magazine, UTNE READER, Nov/Dec. 1994, at 82 [hereinafter Treason] (outlining the ideas and actions of a Race Traitor). See infra notes 165-173 and accompanying text. 
several of our colleagues attacked the new forms of scholarship as nonlegal, unfair, even exclusionary. ${ }^{6}$ Others questioned the role of student-run law reviews. ${ }^{7}$ You had just said something about how we are all creatures of our own narratives, which immediately filled me with alarm. Then the lights went out."

"I figured it was the kids playing at the video arcade next to our booth, and that the lights would be back on agam im a matter of minutes," Rodrigo said." "I saw you put your liead down, assumed you were tired, and got up to stretcli my legs. I thouglit of leaving you a note . ..."

"When I woke up, you were nowhere to be seen," I interjected. "Regular for you, right?" I asked, reaching for two coffee mugs.

Rodrigo nodded. "Thanks. Cream and sugar, please."

"I was afraid you had deconstructed yourself, allowed yourself to become a casualty of Farber, Sherry, Tushnet, and the critique of narrativity." 10

'Nothing so fancy, Professor, althougli I think you'll enjoy the story. In fact, what took place prompted me to come see you. Aside from reassuring you that I haven't expired, I've really wanted to discuss something, if you've got a minute."

"Of course! I'd love to know what happened and what you're thinking. Here we are."

I handed Rodrigo a steaming mug, lie stirred in creamer and his trademark four teaspoons of sugar, and continued. "You won't believe this, Professor, but I was kidnapped."

"Kidnapped? Are you serious?"

"I am. Do you remember those kids who were playing at the video games along the wall?"

"Sure. They borrowed cliange from us once. I remember that they looked at you closely, but thought nothing of it at the time. So what happened?"

"It turns out they were not kids at all, but members of a British antiroyalist gang. This I only found out later. I had just stood up from the table when, quick as a flash, there was a clotli bag over my head, my hands and feet were being tied, and I was carried outside and into a car. The whole thing took maybe thirty seconds."

"My God!" I exclained. "What happened then? And why were they after you?"

6. Delgado, supra note 2, at 548-58.

7. Id. at 556-57 (discussing critique of law reviews and legal scholarship).

8. Id. at 574 .

9. Id. at 563 (descrihing entertainment activities of young teenagers).

10. Id. at 548-51 (summarizing critique of storytelling scholarship by these and other scholars); see also Jane B. Baron, Resistance to Stories, 67 S. CAL. L. Rev. 255 (1994) (responding to the critique). 
"This requires some memory on your part, Professor. Do you recall how I got back to the U.S. that first time?"11

"I do," I said. "It was a neat little two-step maneuver. After you were deported back to Italy, you resettled in Ireland, using your law degree and taking advantage of the liberalized guest-worker provisions in the European Community. You got a job as a paralegal in Dublin, hung around coffeehouses for awhile, then returned to the United States by means of a private bill." 12

"With a hittle help from the Irish Immigration Society and a certain famous U.S. Senator of Irish descent who sponsors these bills routinely. ${ }^{13}$ I'm sure you remember what I did before returning, Professor."

I hesitated a moment, and Rodrigo continued. "I think I mentioned this to you before. I bought a title of nobility from a down-at-the-heels niember of the British aristocracy. ${ }^{14}$ I really wanted to get back and start my LL.M. studies, and didn't want to take any chances. It turned out my investment was probably unnecessary -my American forebears and Italian law degree were probably enough - but that sinall act led to my adventure."

"You mean your kidnappers thought you really were the third duke of Crenshaw?" I asked, beginning to catch on.

"They did. It turned out the group was a collection of exiles just chafing for soinething to do. And when they heard from headquarters that someone on their list was apparently right here in the U.S., they decided to pick me up and give me a going-over."

"But of course their grievance was not with you, but with the real duke of Crenshaw, the one who sold you the title."

"Apparently he was a Royahist and something of a bad actor, from the hiberationists' perspective, at least. The whole thing didn't become clear until they got me to their hideaway."

"Did you have to do sonie fast talking?"

"The team that commandeered ine did. You should have seen their faces when they took the bag off iny head and saw a black man instead of a light-skinned English aristocrat! Their leader was furious. They tried to explain that the restaurant had been dimly lit. They got out the photos. I actually do look slightly like the duke, except for our skin color. I niet him briefly when I paid for the title; we're about the same height, weight, and age. So, their mistake was understandable."

"What happened when they got through blaming each other?"

"That's when $I$ had to talk fast. One of them wanted to give ine a hard time for having bought the title of nobility in the first place. 'A little

11. Rodrigo had been deported from the United States and airmailed a letter to the professor describing the deportation. Delgado, Chronicle, supra note 1 , at 1379.

12. Delgado, Second Chronicle, supra note 1, at 1183-86.

13. Id. at 1186 .

14. Id. 
would-be Englisher' he called me. I could see trouble coming, so I explained to thein how I was a leftist and a race reformer. ${ }^{15} \mathrm{I}$ told them I only became a duke because I wanted to get back to the States. I explained that not only is this my hoineland, but that I had a mission here. They looked dubious at first, then finally gave in when I applied Critical Race Theory to their own anti-royalist moveinent. We ended up going to a local brewpub and debating philosophy and soccer. After a while, they swore me to secrecy for seventy-two hours and drove me back to the hotel. When I got in I tried to look you up, but you had already checked out and headed back to the airport."

"Quite a story," I said. "Reminds ine of Morris Zapp's adventure in Small World."16

"The parallel did strike ine," Rodrigo acknowledged. "Although at the time I wasn't sure it would turn out so well."

"Well, I'in very happy you're back and in one piece."

While Rodrigo took a swig of his coffee, I took the opportunity to reinind him: "But you said you had something you wanted to talk to me about. Did it have to do with your kidnapping?"

Rodrigo leaned forward on my ancient office chair. "It did, in a way. And also with that magazine I brought you. The whole experience got me to thinking of the role empathy plays in our society. The activists who snatched me, even though they were at first taken aback, came around when they learned I was a fellow reformer. At first, I was afraid they'd just throw me off a bridge somewhere. But we ended up comparing notes and having a good time. It turned out we had a surprising amount in common."

"They empathized with your struggle, and you with theirs, in other words." I was silent for a moment. "So, the critique of narrativity caused you to disappear, but empathy brought you back. Awfully tidy, and, I must say, a little upbeat for a young Crit like you," I said, pushing Rodrigo. "Or am I reading you correctly?"

"You and I did talk about the role of empathy once before, Professor. We agreed it is getting in shorter and shorter supply, particularly with respect to minorities of color. ${ }^{17}$ Yet I was able to connect quickly with my

15. See, e.g., Delgado, Chronicle, supra note 1, at 1361-65 (discussing "criteria regression" as designed to exclude minorities from the legal profession and how traditional merit criteria operate as affirmative action for whites); Delgado, Second Chronicle, supra note 1 at 1193 (explaining that the free market will not eliminate racism in American culture but will instead foster narrative explanations to maintain the racist construct); Delgado, Third Chronicle, supra note 1 (argning for a "new civil rights myth" founded on love and justice to expand society's sympathies to now-excluded groups); Delgado, Eighth Chronicle, supra note 1 (describing the social construction of black crime, and pointing out the root causes and overwhelming social costs of white crime).

16. David Lodge, Smali World: An Academic Romance (1984), tells the story of an ambitious academic who is abducted from the Villa Serbelloni in Bellagio, Italy.

17. Delgado, Second Chronicle, supra note 1, at 1187-1201 (describing how Western society is turning an increasingly deaf ear to minorities); Delgado, Third Chronicle, supra note 1, at 403-08, 411- 
captors, once they got over their shock at finding a black man under the bag when they expected a blueblood English aristocrat."

"Maybe there's some level on which marginalized people of all sorts can understand each other," 18 I suggested. "And so, do you think this is something our people can tap into in these troubled tines, when society seens to be devoting less and less attention to our needs, the Republican right is in full cry, affirmative action is under attack, and welfare programs are being cut left and right?"

"No," Rodrigo said, shifting uncomfortably. "I believe the opposite is the case. I'd like to start with a thought experiment that occurred to me as I was being driven back to the hotel."

"I'd love to hear it." began.

Rodrigo drained his coffee mug, set it carefully on my desk, and

\section{I}

RODRIGO'S INQUISPRO EXAMPLE AND THE UNRELIABILITY OF EMPATHY AS A SOURCE OF SUCCOR FOR OUTSIDER GROUPS

"Professor, imagine that some scientific genius develops a computer called Inquispro, which discovers and evaluates the facts behind any litigation and issues an objective ruling. Inquispro can scan any segment of space and time and tell us what happened."

"So, we wouldn't have to rely on witnesses with fading memories, or speculative and inferential evidence," I said.

"Not only that," Rodrigo continued, "but Inquispro knows all the substantive law. We would program it so that it knows the elements of every cause of action or crime."

"So, for example, Smith might accuse Jones of negligence in failing to clear his sidewalks of snow. With Inquispro, we could simply ask the computer to apply the elements of a negligence cause of action to what happened when Smith slipped in front of Jones' house the day of the accident."

"Exactly," Rodrigo replied. "And so with all the other causes of action in the law books. Inquispro could methodically go through all the cases filed, apply the facts to the relevant law and solve thein each in a fraction of a second."

"This would obviously be a great boon to our overworked judiciary," I said. "Indeed, it could eliminate our need for judges and jurors. And there wouldn't be much need for lawyers or law professors, either, althougli I

14 (same); see also Cathy Scarborough, Conceptualizing Black Women's Employment Experiences, 98 Y ALE L.J. 1457, 1467-78 (1989) (discussing ways the law makes black women invisible).

18. See Mari J. Matsuda, When the First Quail Calls: Multiple Consciousness as Jurisprudential Method, 11 Women's RTS. L. REP. 7 (1989) (suggesting that an underlying bond unites all oppressed peoples). Indeed, empathy requires recognition and understanding of others to begin transforming the empathizer. See infra notes $19-65$ and accompanying text. 
suppose someone would have to program the computer with the relevant substantive law."

"Do you remember our recent conversation, Professor, in which we talked about white and black crime? ${ }^{19}$ We discussed the role of discretion and leniency im prosecuting the sorts of crimes that are committed by corporate executives, suburban youth, and governmental figures."20

"Of course," I said. "Everyone knows what happens: the inner city black youth guilty of stealing hubcaps or selling a small amount of drugs is sent away for a long period, while the well-regarded white figure receives probation or a light sentence, even though the latter's crimes inay be more serious, in both a monetary and a physical-safety sense. ${ }^{21}$ And so this is the type of thing your computer could not take into account; differential treatment based upon the race or class of the criminal?"

"That's right," Rodrigo replied. "And so, after a while, society would rebel. We would insist on programming sentencing discretion and pleabargaining laxity into the computer. Otherwise automobile executives would receive long sentences when one of their poorly designed cars killed someone. Savings and loan executives would receive fifty-year sentences. ${ }^{22}$ And so on."

Seeking to play the devil's advocate, I imterjected. "But doesn't a sentencing system $\mathrm{m}$ which the jury decides on the appropriate punishment, either in the sentence itself or through the choice of offense, provide exactly the discretionary empathy whose absence you deplore? Don't we need a jury, influenced by witnesses, lawyers, and the courtroom itself, to reflect our cominunity's sense of reasonable conduct, morality, and approbation?"

"That's right," Rodrigo explained calmly, leaning back in what must be by now a very uncomfortable chair. "But empathy is apt to be quite selective. Society's rejection of Inquispro shows that we expect a judicial system that recognizes the individuality of white defendants, but not black ones. Take the federal sentencing guidelines for drug offenses. Judges in these cases, in which the defendants are overwhelmingly poor and of color, are statutorily prevented from considering leniency in sentencing. ${ }^{23}$ No such requirements exist, to my knowledge, for securities fraud, tax evasion, or environmental pollution."

The impact of what Rodrigo was saying sank in on me. "So, Rodrigo, you are saying that society would never tolerate Inquispro. A genuinely fair

19. Delgado, Eighth Chronicle, supra note 1.

20. Id. at 525-32.

21. Id. at 522-32, app. B at 547-48 (arguing that white-collar and corporate crime are more physically dangerous and costly in an aggregate and a per capita sense than street crime). Nevertheless, lenient or non-penal sentences are often imposed because of a perception that white-collar criminals are more sensitive or redeemable. Id. at 525-26\& n.71.

22. See id. at 525-26.

23. See U.S. Sentencing Comm'n, Federal Sentencing Guidelines Manual §§ 2D1.1-2D3.2 (1994) (prescribing minimum sentences for offenses involving drugs). 
judiciary that provided equal justice for whites and blacks would be intolerable. We would insist on reprogramming Inquispro so that it was, basically, racist. So that it had a bias in favor of clean, neat, well-educated white defendants and against black ones, in favor of upper-class people of all colors and against poor ones."24

"We would. Otherwise, society wouldn't accept it."

"And the inoral you draw from this fiendish experiment, Rodrigo, is . . ?"

“Our society doesn't really want empathy for outgroups or minorities, any more than it wants equal treatment for all people. ${ }^{25}$ Quite the contrary, we prefer preferential treatment for ourselves and our kind. We would never accept anything less than that, in fact."

"Which is what your Inquispro example shows," I replied glumly. I took the chance to offer Rodrigo another mug of coffee (had he ever declined, I wondered?).

Rodrigo glanced at my shiny black coffee machine, nodded enthusiastically and held out his cup. As he was stirring in his condinnents, I asked, "And I gather you think this lack of empathy is somehow responsible for our current predicament?"

"I do. I've been thinking about it a great deal," Rodrigo explained, cupping both hands around the now-hot mug. "Although I hope you won't jump on ine for the rough form of my ideas, Professor. I've developed not so much a theory as a way of seeing why things aren't better for our people. I'll be glad to tell you about it, if you have the time."

24. See Delgado, Eighth Chronicle, supra note 1 at 519-20 \& nn.57-58, 69 (citing statistics demonstrating that most white-collar and corporate crimes are committed by whites).

25. On the decrease in empathy generally, or the need for the law and legal discourse to be more empathic, see, e.g., Elizabeth V. Spelman, Inessential Woman: Problems of Exclusion in FEMINIST THOUGHT 11-15, 177-87 (1988) (arguing that white feminists must recognize the differences of class and race among women); Anne C. Dailey, Feminism's Return to Liberalism, 102 Y ALE L.J. 1265, 1278-85 (1993) (book review); Richard Delgado \& Jean Stefancic, Images of the Outsider in American Law and Culture: Can Free Expression Remedy Systemic Social Ills?, 77 CoRnelz L. Rev. 1258 (1992); Lynne N. Henderson, Legality and Empathy, 85 MrCH. L. Rev. 1574 (1987) (arguing that Iegal decision making does not embrace an understanding of human experiences); see also Natalie Angier, Society's Glue: Science Examines Empathy's Role for Man, Beast, DeNVER Post, May 9, 1995, at $2 \mathrm{~A}, 4 \mathrm{~A}$ (quoting a leading scientist who points out one drawback of empathy: that identification with one's in-group tends to be accompanied by dislike of other groups); Scarborough, supra note 17 (arguing that courts must view black women within the context of their past and present experiences).

For the view that empathy is no replacement for legality, see Toni M. Massaro, Empathy, Legal Storytelling, and the Rule of Law: New Words, Old Wounds?, 87 Mrcr. L. Rev. 2099 (1989). For a critique of empathy that to some extent parallels Massaro's but focuses on empathy's role in liberal and communitarian political theory, see Cynthia V. Ward, A Kinder, Gentler Liberalism? Visions of Empathy in Feminist and Communitarian Literature, 61 U. CHr. L. Rev. 929 (1994).

For various definitions of empathy, see id. at 933-34 (offering psychological, scholarly, and common-sense definitions of empathy). Rodrigo and the professor use the term in its ordinary-language seuse-the capacity to project or imagine the thoughts and feelings of another person. 
"I do, although I don't want to make you late for dinner. Is Giannina expecting you?"26

"She's attending a writer's workshop uptown. My schedule's my own tonight, although I may want to borrow your phone later, if it's okay, and give her a call. We usually talk to each other around dinner time when one of us is away doing something."

"Of course," I replied, pointing at the phone. "Anytime you want. I'll punch in the code, and give you privacy."

"Thanks, Professor. Maybe a little later. And no, I won't be needing privacy. Giannina considers you almost one of the family."

"I'm honored. But tell me more about your theory of empathy. And incidentally, if you get hungry, let me know. I have snack food in the refrigerator ..." I indicated my small office fridge, which I had recently purchased and of which I was proud. "Or we could go out for a bite."

"Thanks a lot," Rodrigo said, siniling. "Maybe a little later. Back to our subject. I start with two observations. One is that empathy is highly limited. Not only is it in short supply, but it also tends to become rarer over time. ${ }^{27}$ And the second is that we think we-and others-have much more einpathy for the downtrodden than we, in fact, do. ${ }^{28}$ I even have a name for this. You've heard of Gramsci's concept of false consciousness?"29

"Of course," I said, a hittle sharply. (These impudent young pups soinetimes think us old-timers haven't read anything!) "Gramsci coined the term to mean the kind of identification with the aggressor that a subjugated people can easily develop. They imternalize the perspectives, values, and points of view of the very people who conquer and oppress them, thus becoming unconscious agents in their own subordination.",30

"And so false consciousness is a danger for blacks, at least if we aren't careful. ${ }^{31}$ But have you ever wondered, Professor, if there is anything comparable for whites?"

26. On "Giannina," Rodrigo's companion and soul mate, see Delgado, Third Chronicle, supra note 1, at 402 (introducing Giannina); Delgado, Fourth Chronicle, supra note 1, at 1137 (describing Giannina's production of a "counter-parody" satirizing law schools' reliance on wealthy donors); Delgado, Sixth Chronicle, supra note 1, at 639-42, 672 (describing Giannina's role in a debate on essentialism and feminist legal theory). Giannina, a published poet and playwright, and Rodrigo have been together for nearly two years.

27. See infra notes $61-65,75-84$, and accompanying text (explaining why this is so).

28. See infra notes 32-39, 54-56, 63-65, 70-74 and accompanying text (explaining this phenomenon).

29. See Georg Lukacs, History and Class Consciousness 72 (Rodney Livingstone trans., MIT Press 1971); Duncan Kennedy, Antonio Gramsci and the Legal System, 6 ALSA F. 32, 36-37 (1982).

30. See LukAcs, supra note 29 , at 72 ; Kennedy, supra note 29 , at 36-37.

31. Blacks and other people of color could identify with and take on the consciousness of the more powerful whites, for example by internalizing blanie or self-doubt, or by distancing themselves from affirmative action as certian famous hlack and brown neoeonservatives have done in recent years. E.g. Stephen L. Carter, Reflections of An Affirmative Action Baby (1991); Richard Rodriguez, 
"Comparable to false consciousness, you mean?" I wasn't sure what Rodrigo was driving at.

"I think there is, and it's empathy. Or rather, what I call false empathy, in which a white believes he or she is identifying with a person of color, but in fact is domg so only im a slight, superficial way." two."

"It is a kind of parallel," I said. "But I think I could use an example or

"Sure," Rodrigo replied. "Consider the early Settlement House movement. $^{32}$ The upper-class ladies who worked there professed to be highly concerned over the plight of the immigrants who lived in the houses. But their sympathies did not extend to learning their languages or ways. Instead, they taught them personal hygiene, housekeeping, English-how to be American. ${ }^{33}$ Lawyers make this mistake, too, even public interest ones. Maybe especially public interest ones."

"I assume you are referring to Derrick Bell's famous article," I asked. "The one about serving two masters?"34

"That one and others. Bell points out that lawyers working on behalf of black groups would often pursue one strategy, favored by the litigation team-say, desegregated schools-when what the client really wanted was better schools, ones with more resources. ${ }^{35}$ And sometimes even the best clinicians make similar mistakes."36

Rodrigo continued. "My friend Kowalski and I were talking about this the other day. ${ }^{37}$ Even $\mathrm{m}$ those client-centered aspects of law like clinical scholarship, real empathy is lacking. Some of the young star scholars admit they sometimes make the mistake of thinking they know what the client wants, and imagine that they are able to tell the client's stories as he or she would want them told. ${ }^{38}$ Real empathy, putting the client first and getting fully inside the client's mind and experience, is rare."

Hunger of Memory (1981); ThOMas Sowel, CIVIL Rughts: Rhetoric OR ReALITY (1984); Shelby Steele, The Content of Our Character (1990).

32. See Jane Addams, Twenty Years at Hull-House (Signet Classic 1981) (1910); HANDBOOK OF SETTLEMENIS (Robert A. Woods \& Albert J. Kennedy eds., Amo Press, 1970) (1911) (describing the education these houses provided for their members); Howard J. KARGER, THE Sentinels of Order: A Study of Soclal Control and the Minneapolis Settlement House Movement, 1915-1950 (1987); Harry P. Kraus, The Setrlement House Movement in New York CITY, 1886-1914 (1980).

33. See, e.g., AdDams, supra note 32; Peard I. Eluis, Amerucanization Through Homemaking 19-29 (1929) (describing course of instruction for Mexican immigrant girls in U.S. schools); KARGER, supra note 32.

34. Derrick A. Bell, Jr., Serving Two Masters: Integration Ideals and Client Interests in School Desegregation Litigation, 85 Y AIE L.J. 470 (1976).

35. Id. at $470-72,482-93$.

36. See infra notes $51,89,121-123,141-146$, and accompanying text.

37. On "Kowalski," Rodrigo's young and equally brilliant conservative friend and colleague, see Delgado, Tenth Chronicle, supra note 1, at 1713.

38. See infra notes 40-44, 51, 89, 121-124, 135-147, and accompanying text (discussing empathy in clinical thcory). 
"So, you are saying," I summarized, "that when a white empathizes with a black, it's always a white-black that he or she has im mind. The white surmises what he would be like if he were black, but with his same wants, needs, perspectives, and history. All grounded in white experience, of course." 39

"Right. False empathy, a sentimental, breast-beating kind, is common among white liberals, and is the mirror opposite of false consciousness, Gramsci's notion."

"Nice and neat," I said. "Like the periodic table." In truth, I was a bit stunned by the clear polarity Rodrigo had just outlined. His false empathy construct went soine way, I thought, toward explaining how decades of liberal civil rights and legislative policy have left our people only inarginally better off.

"False einpathy is not just an elegant explanation," Rodrigo continued. "It has real consequences for civil rights strategy. With false consciousness, a person of color identifies with and adopts the consciousness of the oppressor, in this case a white. With false einpathy, a white pretends to understand and synnpathize with a black. Each is counterfeit. The first type, the upward climber, is readily recognized and unmasked. These are the Great Gatsbys, and they tend to be objects of ridicule by both whites and blacks. ${ }^{40}$ The second, false empathy, is likewise despised-but by blacks. We see through it, know by a kind of instinct that these folks won't be with us when trouble comes down. ${ }^{41}$ Derrick Bell got it right in his Serving Two Masters article. ${ }^{42}$ Gerald López, in Rebellious Lawyering, ${ }^{43}$ did, too. But some of the top clinical theorists are getting it wrong, satisfying themselves and their clients with too little. A recent article shows how cognitive- and narrative-theory barriers render empathy difficult, a inechanism the authors call the "empathic fallacy."

"You inake it sound as though the problem lies inostly on the white folks' side. Don't our people sometimes comınit the same inistakes?"45

39. See, e.g., SPELMAN, supra note 25 , at 12 (describing "boomerang perception" in which "white children like me ... were told by well-meaning white adults that Black people were just like us-never, however, that we werc just like Blacks."); see also Ward, supra note 25, at 942-45.

40. See F. Scott Ftrzgerald, The Great GatsBy (1925) (describing an upward-climbing opportunist who seeks to attain social recognition through calculated means; Gatsby is unmasked, however, when he cannot suppress his lower-class origins in interacting with the Long Island gentry).

41. See Thomas B. Edsall, "New" Image of Democrats Emerges Under Clinton, WASH. Post, Jan. 27, 1994, at A6.

42. See Bell, Serving Two Masters, supra note 34.

43. Gerald P. López, Rebellious lawyering: One Chicano's Vision of Progressive Law Practice (1992).

44. Delgado \& Stefancic, supra note 25 , at 1261,1281 ; see also Lucie E. White, Seeking "... The Faces of Otherness ...": A Response to Professors Sarat, Felstiner, and Cahn, 77 CORNELL L. Rev. $1499,1508-11$ (1992).

45. I was thinking, for example, of how no black civil rights organization had filed an amicus brief in Korematsu v. United States, 323 U.S. 214 (1944) (holding exclusion, relocation, and internment of Japanese Americans does not violate Fourteenth Amendment), and of how some men of color still 
"They do, sometimes." Rodrigo conceded. "Although I think less frequently. Most whites lack double consciousness. ${ }^{46}$ As members of the majority culture, they have little practice viewing experience from two perspectives at once. We have to do so regularly."

"Someone who is im the grip of false empathy has a shallow identification with the other," I added. "He or she walks on the surface, uses the wrong metaphors and comparisons. ${ }^{47}$ It's a little bit like false piety, like those folks who go to church on Sunday but don't allow themselves to be seized by real religion."

"The most unsympathetic thing you can do is to think you have empathy with those of a radically different background. You can easily end up hurting them."

"You mean by doing the wrong thing, by not supplying what they need?" I asked.

"Even worse than that," Rodrigo replied. "Are you familiar with the story of La Malinche?"48

I was silent for a moment, straining to remember. "You mean Hernan Cortés's translator?"

"Yes," Rodrigo replied. "I was talking with one of my Latina students the other day about her. La Malinche was a Native American woman who served as Cortés's translator. She ended up helping Cortés destroy her own people." $" 49$

"I think our Mexican friends have a phrase for it."

patronize the women in their lives. See Delgado, Sixth Chronicle, supra note 1, at 647 (discussing this and other unlovely traits).

46. For the classic description of double consciousness, in which blacks see themselves simultancously from two perspectives-from that of the outside world, in which they are ignored or despised, and from their own, in which they are empowered and free, see W.E.B. Du Bo1S, THE SouLs OF BLACK FolK 1-12 (Kraus-Thomson 1973) (1903):

It is a peculiar sensation, this double-consciousness, this sense of always looking at one's self through the eyes of others, of measuring one's soul by the tape of a world that looks on in amused contempt and pity. One ever feels his two-ness,- - an American, a Negro; two souls, two thoughts, two unreconciled strivings; two warring ideals in one dark body, whose dogged strength alone keeps it from being tom asunder.

Id. at 3; see also Ralph Ellison, INVISIBLE MAN 3-7 (1952).

47. On the way metaphors and analogies can sometimes flatten and decrease understanding of the other's situation, see generally SPELMAN, supra note 25 (discussing the role of categories and conceptual errors in confining thought related to women and women's roles). See Trina Grillo \& Stephanie M. Wildman, Obscuring the Importance of Race: The Implications of Making Comparisons Between Racism and Sexism (Or Other -Isms), 1991 DuKE L.J. 397, 398 ("The analogy makes the analogizer forget the difference and allows her to stay focused on her own situation without grappling with the other person's reahity."); Ward, supra note 25, at 944-45 (discussing the limits of "projective" empathy).

48. I am grateful to Margaret Montoya for this example. Private communication from Professor Montoya, June 1995.

49. On Cortés's (and La Malinche's) role, see, e.g., 1 William H. Prescott, History of the CONQUEST OF MEXICo bk. II, ch. V, at 184-86, bk. III, ch. V, at 296 (Everyman's Library 1909) (1847); see generally Bernal Diaz del Castillo, The Discovery and Conquest of Mexico 1517-1521 (A.P. Maudslay trans., 1956) (providing contemporary account of the conquest by participant in three expeditions, including that of Cortés). 
"They do," Rodrigo replied. "La traducción es traición. ${ }^{50}$ Translation is treason. One who moves too easily back and forth between different communities can end up betraying the one with the least power, simply by making its secrets accessible to the other. Clinical theorists, some with the most impeccably liberal credentials, worry that they are doing something similar when they spill a client's stories out on the pages of a law review for all to read. .51

I stood up to switch my espresso machine to warm. "I'd love to come back to this later, Professor," Rodrigo remarked. "But can I interest you in a bite of dinner? I think I'm hungry, after all."

"You certainly can," I replied, looking at my watch. "And if we hurry, we can get to some good places before they fill up."

II

\section{Rodrigo Explains how EMPathy, LiKe KNOWLEDGe, Reproduces Hierarchy and Why GenuINe SYMPATHY IS IN SHORT SUPPLY}

We walked briskly down the sidewalk in front of my law school. "Is Vietnainese okay?" I asked. "This new place opened a couple of months ago. I haven't been there yet, but everyone tells me the food is great and the service good."

"Cool," Rodrigo replied casually. A few minutes later we were seated in a comfortable booth in the homey, dark restaurant. While waiting for the waiter to take our orders, I picked up our discussion where we had left off in my office. "Rodrigo, let me see if I understand you. Are you saying that empathy is bad, per se, or that it is good, but there is too little of the real article to go around?"

"In a way, both," Rodrigo replied, looking up at the waiter who had just brought our menus. After examining our options, we ordered appetizers and beverages (yet another cup of coffee for iny irrepressible friend, herbal tea for ine). "Empathy can harm if it's not genuine, as it often is not. Like knowledge, it has a power dimension. ${ }^{52}$ Empathy reproduces hierarchy. And the real kind, true empathy, is in extremely rare supply."

"Tell me about how the false, or superficial kind reproduces hierarchy," I asked. I had just been reading about the sociology of knowledge,

50. See supra note 48.

51. C.f. Clark D. Cunningham, The Lawyer as Translator, Representation as Text: Towards An Ethnography of Legal Discourse, 77 CorNeLl L. REv. 1298, 1383-84 (1992) (describing how client insisted on being named in article so as not to replicate the anonymity he experienced throughout his case).

52. See Mrcher Foucault, Power/Knowledge: Selected Interviews and Other Writings 1972-1977 (Colin Gordon ed. \& Colin Gordon et al. trans., 1980). 
and was intrigued by Rodrigo's notion that emotions might reinforce the status quo just as knowledge does..$^{53}$

"We mentioned the case of La Malmche a minute ago. A member of the oppressed group tells the oppressor what it wants to know. The more powerful group then uses the information to destroy the translator's group."

"The translator is a dupe, in other words," I said.

"It works the other way, as well," Rodrigo went on. "Some liberals write about horrible conditions in the community, believing that others will want to remedy them. Their readers may draw the opposite conclusion, however - that minorities are lazy, slothful, like to live that way, and so on. ${ }^{54}$ And there is a third way, in which the liberal does not actively harm the member of the weaker group, but inerely does him no good. The Good Samaritan offers the wrong sort of rescue.

"Like the Settlement House ladies we were talking about before. They taught Italian immigrants how to cook and eat American food, although they already had perfectly satisfactory recipes and cuisines. The ladies urged iminigrant mothers to use bottles and infant formula instead of breast feeding, which they considered un-American and not modern."ss

"It's what you were saying earlier," I interjected. "When we visualize helping another person, we end up helping ourselves in the form of that other person. ${ }^{56} \mathrm{~A}$ white helps a black who is, in effect white: a postulated recipient who will like and appreciate what the white would have wanted had the white been in exactly that situation. A church group helps the starving, but makes them pray first."

53. See id.; see also Thomas S. Kuhn, The Structure of Scientific Revolutions (2d ed. 1970) (explaining that scientific research is based on paradigms, or key past scientific achievements, and that revolutionary advancements in science do not occur until these paradigms are reinterpreted or discarded).

54. E.g., Office of Policy Planning and Research, U.S. Dep't of Labor, The Negro FAMILY: THE CASE fOR NATIONAL ACtion (1965), which was written in an effort to understand and help, is today considered virtually an argument for abandoning hope for that "patbological" institution, the black family; see also KrIstin BumILleR, THE CIVI Rights SocIeTY: The Social Construction of Victrms (1988) (book by progressive scholar, based on interviews with victims of discrimination, whose general thesis is used by some to argue against civil rights laws and enforcement on the ground that they simply encourage a victim mentality); DaNIEL P. MOYNIHAN, FAMILY AND NATION (1986); Charles J. Sykes, a Nation of Victmis: The Decay of the American Character (1992) (lamenting the "politics of victimization" in U.S. society); PATRICIA A. TURNER, I HEARD IT THROUGH tHe Grapevine: Rumor IN African AmERICAN Culture (1993) (describing urban myths that cireulate in the black community as efforts to increase solidarity and empowerment; however, drawing attention to these myths may risk making the community look ignorant and ridiculous). On the possibility that "imaginative" empathy can reinforce hierarchy, see Ward, supra note 25, at 949-52.

55. See supra note 32.

56. See supra notes 34-39. On this danger, see also LaWrence C. BeCKER, RECIPROCITY 158-59 (1986); Henderson, supra note 25, at 1651; Duncan Kennedy, Distributive and Paternalist Motives in Contract and Tort Law, With Special Reference to Compulsory Terms and Unequal Bargaining Power, $41 \mathrm{MD}$. L. REv. 563 (1982). On the difficulty of cross-cultural identifieation and empathy, see CLIFFORD Geertz, Local Knowledge: Further EsSays in lnterpretive ANTHRopology 55-70 (1983). 
'T'm sure you've noticed, Professor, that people almost always give presents that they would like to receive themselves?"

I remembered with a pang a time or two when my late wife had scolded me for doing soinething similar. "It's something of a joke with married folks," I said. "The husband gives the wife a lug wrench. She gives him two tickets to the opera, and so on."

"So you see what I mean about the way einpathy reproduces power relations," Rodrigo said. "And also how it can sometimes amount to outright betrayal."

We fell silent while the waiter set down our appetizers, some sort of skewered chicken for my rail-thin friend, a pungent hot-and-sour soup for me.

"You were also going to explam why it is in such short supply," I said, ladling myself a spoonful of the steaming delicacy. "The real kind, I inean. And I believe you were also going to explain why the other kind is not inerely harmful, but can kill."

Rodrigo removed his chicken inorsels froin the skewer, neatly speared one with his fork, and began:

\section{A. Rodrigo Explains Why Empathy Is in Short Supply}

"Empathy ought to benefit the possessor," Rodrigo explained, "because it enables him or her to nnake beneficial trades. If one has the ability to perceive what the other person wants, one can offer him or her that and get what one wants in return. Our law and economics friends would say it promotes marketplace efficiency. ${ }^{57}$ Empathic people ought to get ahead. The capacity ought to confer an evolutionary advantage, enabling its possessors not merely to be good parents, friends, and lovers, but good traders, politicians, and marketers."

"But you believe things are not working out that way?" I asked.

"No. For some reason, the evolutionary momentum seems to have stopped, even reversed itself, with respect to people of color. I've been trying to figure out why this is so."

"No one can doubt that it is. Civil rights, affirmative action, Head Start, and dozens of other programs necessary to our people are under attack. $^{58}$ The codes used by politicians and writers when casting aspersions

57. E.g., Richard A. Posner, Economic ANalysis of Law (4th ed. 1992) (arguing that law should promote the maximization of voluntary trades and transactions in order to satisfy individual and market preferences).

58. See, e.g., Adarand Constructors, Inc. v. Pena, 115 S. Ct. 2097 (1995); ANDrew HACKER, Two Nations: Black and White, Separate, Hostile, UNEQUal 50-52, 93-133 (1992); Amy Wallace, UC Decision Threatens Diversity, Report Finds, L.A. Tmes, Dec. 14, 1995, at A3 (describing predicted impact of decision to end affirmative action in University of California admissions); Yumi Wilson, AntiAffirmative Action Drive Begins, S.F. CHroN., Sept. 29, 1995, at A26 (describing proposed California ballot initiative that would abolish most state affirmative action programs). 
on us have become blatant and obvious. ${ }^{59}$ Black parents believe that things are now the worst they have been in more than a century, that their children will be denied jobs or educational opportunities because of discrimination, and that their sons are in constant danger from violence and drugs. ${ }^{60}$ And I gather you think this is not just an aberration or part of an ordinary political cycle."

"I wish it were," Rodrigo replied. "But the downturn in our fortunes is more serious than that. I think the increasmg bureaucratization of modern life $^{61}$ may account for part of the decrease in enipathy and patience for the downtrodden. Modern social relations are apt to be distant and perfunctory. We may run across a few people of radically different classes or races from time to time, but we seldom mteract closely witli them. A new branch of social psychology called norm theory ${ }^{62}$ may supply part of the answer, as well."

I strained my memory. "Norm theory?" I asked.

"Yes. Norm theory holds that our reaction to another person in distress varies according to the normalcy or abnormalcy of his or her plight in our eyes. ${ }^{63}$ If you see an upper-class white family being evicted from their nice suburban home, you feel alarmed because you know that sort of situation is abnormal for them. You realize they must be experiencing real distress. But if you see starving Biafrans on TV, you feel less enipathy because you know that is their ordinary situation. Famines are common in that part of the world, so your heart does not go out to them as it would to a neighbor who materialized on your doorstep not having eaten in eight days."

"I've read of experiments dealing with helping behavior that appear to bear that out," I said. "In one, a black nian in the subway asks for change for a quarter and is refused; a white man does the same and is given

59. I thought of Willie Horton, and Jesse Helms's "white hands" commercial, and of the Wall Street Journal's "quota queen" slur on Lani Guinier. Also of the way many politicians havc heen rallying around such neo-nativist themes as immigration control and English Only, which are aimed at making life difficult for Latinos and other recent arrivals. See, e.g., Richard Lacayo, For Whom the Bell Curves: A New Book Raises a Ruckus by Linking Intelligence to Genetics and Race, Time, Oct. 24, 1994, at 66; Tom Tancredo, Make a Candidate Sweat-Ask About Illegal Immigrants, DeNVER Post, Apr. 30, 1995, at 1E; Anthony Walton, Willie Horton and Me, N.Y. Trmes, Aug. 20, 1989, $\S 6$ (Magazine), at 52; Isabel Wilkerson, Racial Harassment Altering Blacks' Choices on Colleges, N.Y. TMEs, May 9, 1990, at Al.

60. Richard Whitmire, "Major Crisis" for Black Children: Adults in Poll: It's Worst Times Since Slavery, Denver Post, May 27, 1994, at 2A.

61. See Richard Delgado, Norms and Normal Science: Toward a Critique of Normativity in Legal Thought, 139 U. PA. L. REv. 933, 957 (1991); Pierre Schlag, Normativity and the Politics of Form, 139 U. PA. L. REv. 801 (1991) (discussing use of normative discourse by bureaucrats interested in routine and sameness).

62. See, e.g., Daniel Kahneman \& Dale T. Miller, Norm Theory: Comparing Reality to Its Alternatives, 93 Psychol. Rev. 136 (1986).

63. "The event will then appear normal if it confirms expectations, abnormal or surprising if it violates them." Id. at 137. 
change. ${ }^{64} \mathrm{I}$ had thought these experiments manifested simple racism, but maybe they illustrate your phenomenon as well. Everyone assumes the black person has a rough road in life, so hardly anyone will stop to help."

"Experiments with stranded motorists show mucl the same thing,"65 Rodrigo added. "Norm theory explains why empathy decreases over time, even though it would seem to benefit the possessor. The poorer and more wretched blacks become, the less white people will empathize with thein. They will dismiss our cries of pain, thinking to themselves that they are part of our normal condition."

"And the poorer and more wretched we become, the less we will have to offer in trade. Empathy with us will be useless. Who wants to trade with a slave who has nothing to offer? There is no reason for empathy with one who is permanently destitute."

"My point exactly," Rodrigo continued. "Empathy is least useful where we need it most. When inequality is deep and structural, empatlyy declines. It's a downward spiral. Einpathy would work in a just world, one in which everyone's experience or access to resources was roughly the same. But we don't live in a world like that."

"Is there any solution, any liope?" I asked.

"The only one I see is to show that our people have something to offer whites. We were talking about this the first time we met. ${ }^{66}$ If one can convince white folks in elite positions that blacks are necessary to them, have something to offer, our treatment will shift overmight, as it did in wartime. ${ }^{67}$ The prevailing narratives and inyths will cliange magically to facilitate the trades and exchanges, services, and so on that the dominant group needs. None of this will take place on a conscious level."

"The trouble is that many of thein seem ready to write us off. The Republicans now realize they don't need our votes. They can count on backlash voters, angry white males, ${ }^{68}$ while the Democrats seein not to want us, either. ${ }^{69}$ And, if I understand your argument, our few remaiming

64. See Faye Crosby et al., Recent Unobtrusive Studies of Black and White Discrimination and Prejudice: A Literature Review, 87 PsYchol. BuzL. 546, 548-52 (1980) (reviewing extensive "helping behavior" studies on American racism).

65. See Stephen G. West et al., Helping a Motorist in Distress: The Effects of Sex, Race, and Neighborhood, 31 J. Personaltry \& Soc. PsYchol. 691, 693-94 (1975) (finding that victims were helped primarily by persons of the same race: $97 \%$ of those who helped black victims were black, while $94 \%$ of those who helped white victims were white); see also Crosby et al., supra note 64 , at 548-52 (finding motorists more likely to help stranded person of their own race).

66. Delgado, Chronicle, supra note 1, at 1366-76 (arguing for the need to provide whites a selfinterested basis to support affirmative action and racial justice).

67. Id. On the economic-determinist (interest convergence) view of eivil rights law, see DerRICK A. BELl, JR., RACE, RACISM, AND AMERICAN LAW 1-51 (3d ed. 1992); Derrick A. Bell, Jr., Brown v. Board of Education and the Interest-Convergence Dilemma, 93 HARV. L. REV. 518, 522-33 (1980).

68. On the backlash vote and role of angry white males, see David Gates, White Male Paranoia, NewwSWEEK, Mar. 29, 1993, at 48.

69. See Richard Delgado, Zero-Based Racial Polities: An Evaluation of Three Best-Case Arguments on Behalf of the Nonwhite Underclass, 78 GEo. L.J. 1929 (1990) (arguing that the nonwhite 
liberal friends can't be counted on because their empathy is shallow. They think they know what we need, but don't. They visualize themselves in our places, and ask what they, themselves, would want."

"False empathy is worse than indifference, Professor. It encourages the possessor to believe he is beyond reproach. It's like a certain type of religiosity. If you believe you are saved, you can easily come to believe that you can do no wrong. ${ }^{71}$ Because you believe in God, you will believe you are God, or at least that you're in tight with Him. He's on your side; you understand each other. Once you reach this poimt, you can do no evil, as you are God-or at least His messenger."

"You will then think you are being extremely empathic, as the Spanish conquistadores did, because you are acting on behalf of God in the other person. ${ }^{72}$ Not what that other person is, but what he or she might be. The other person may not believe he or she has that God in him or her. But you will know better. Is that your general idea?" I asked.

"Yes," Rodrigo said. "In fact, I'm reminded that studies like the helping experiments we were talking about have shown that religious people did not help out any more than non-believers. ${ }^{73}$ For example, in one experiment, seminary students were no more likely than anyone else walking down the street to stop to help a man who was slumped over and groaning in a doorway. Iromically, some of the students were on their way to give a talk on the parable of the Good Samaritan."74

"So ideology of all sorts decreases empathy," I summarized. "It allows one to exclude different or challenging ideas as outside the accepted paradigin. And the more politically fractured our nation becoines, the less important will seem its commitnent to racial justice and help for the poor. ${ }^{75}$ Religiosity also decreases empathy, all things being equal, ${ }^{76}$ as does bureaucracy. ${ }^{77}$ And the conditions of modern life add a fourth element: as the gap in earnings and family wealth between blacks and whites grows

poor should consider "zero-based" politics, including throwing support behind the liberal wing of the Republican party).

70. See supra notes 32-56 and accompanying text.

71. See, e.g., Delgado, supra note 61 , at 954-55.

72. On some of the cruelties committed by the early conquistadores, see generally DiAz, supra

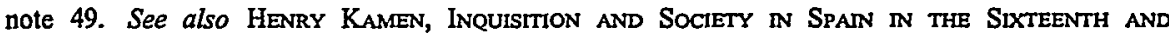
Seventeenth Centuries (1985). On a U.S. experience, see Arthur Miller, The Crucible, in Collected Plays (1957) (giving fictional account of the Salem witch trials).

73. See Alfie Kohn, Between God and Good: Research Shows Believers Are No More Likely to Love Their Neighbor Than Nonbelievers, S.F. Chron. \& EXAMnner, July 8, 1990, ThIs WorLd, at 15 (summarizing various studies of leiping behavior).

74. Id. On the false piety of self-rightcous belief, see Peggy C. Davis, Law as Microaggression, 98 Y ALE L.J. 1559 (1989) (describing minoritics' perception of bias despite the legal system's expressed commitment to egalitarian ideals).

75. See supra notes $68-70$ and accompanying text (summarizing this argument).

76. See supra note 71 and accompanying text.

77. See supra note 61 and accompanying text. 
wider, there is less to trade. ${ }^{78}$ With the decreased reward in understanding and empathizing with the other, empathy naturally decreases. And the poorer those others get, the more norm theory clicks in. Their poverty begins to seein natural and unsurprising, and thus there is no urgent need to remedy their misery."

"And don't forget the decreasmg pie," Rodrigo added. "The slowing of job and income growth for the middle class, combined with the competition froin foreign workers and inarkets, ${ }^{79}$ means that there is correspondingly less empathy to go around. The reason is that socioeconomic competition, as you know, increases racism as well as decreases empathy. ${ }^{80}$ As one's own well-being and security decrease, one looks to oneself and one's friends. Expanding narkets give a reason for increased empathy: smce one is in a position to make trades, understanding other people and their needs confers an advantage. ${ }^{81}$ One can trade with the newcomers. Bad tines cause you to hunker down and conserve what you already have. During human evolution, the main function of empathy was to facilitate bonding and solidarity, so that collectivities could form. ${ }^{82}$ But with racism, a relatively new phenomenon, the attitude promotes white bonding, white solidarity. This benefits ehte whites, since it ensures that struggling white workers won't turn against them..$^{83}$ And it consoles those workers. Even though their share of the pie gets smaller and sinaller, they can say to themselves that they're at least better off than the blacks."

"In sum, six factors that augur little good for our people," I said. "A pretty gloomy scenario, coming from someone as young and upbeat as you. I hope you have a solution. Does it include law?"

78. On the wage gap between blacks and whites, see Spencer Rich, Blacks Lose Ground with Jobs Despite Education Gains, Study Says, WASH. Post, Apr. 30, 1995, at A8; Delgado, Chronicle, supra note $\mathrm{I}$, app. $\mathrm{D}$ at 1382 (collecting sources).

79. Delgado, Chronicle, supra note 1, at 1369-70, 1375, app. A at 1381.

80. On this socioeconomic theory of racism, see, e.g., Gordon W. Allport, The NATURE of Prejudice 224-25 (1954); Joel. Kovel, White RAcisM: A Psychohistory 44 (1970).

81. On empathy and trades, see supra notes 56-57 and accompanying text.

82. On this biological theory of empathy, see, e.g., Robert L. Trivers, The Evaluation of Reciprocal Altruism, 46 Q. Rev. B1ology 35 (197I); Frans B. M. De Waal, The Chimpanzee's Sense of Social Regularity and Its Relation to the Human Sense of Justice, in THE SENSE OF Justice: BiologicaL Foundations of LAw 241 (Roger D. Masters \& Margaret Gruter eds., 1992).

83. Derrick Bell is one of the primary proponents of this functional view of racism. See BELL, supra note I (arguing that white prejudice unites working-class and elite whites and keeps the former from challenging the latter); Bell, Brown v. Board of Education, supra note 67, at 525-26 (arguing that poorer whites had relied on expectation that elite whites would enforce poor whites' superior social status over blacks, and felt betrayed by whites who supported desegregation).

84. BELL, supra note 1; see also Derrick Bell, Racism: A Prophecy for the Year 2000, 42 RUTGERS L. REv. 93, 96-108 (1989) (recounting and analyzing The Chronicle of the Space Traders; arguing that the costs of social remedies are invariably placed either on blacks themselves or on lowerclass whites, and that a prime mechanism of white supremacy is to ensure that lower-class whites view blacks as their enemies rather than the elite whites who benefit from their oppression); Derrick Bell, After We're Gone: Prudent Speculations on America in a Post-Racial Epoch, 34 ST. LouIs U. L.J. 393 (1990) (presenting same chronicle in slightly revised form with additional commentary). 
"Oh, here's our waiter," Rodrigo interjected. "Can I tell you in a ininute?" We both examined the inenu in silence, while the waiter waited patiently.

"I'll have number twenty-seven," Rodrigo said.

"And I'll take thirteen. It doesn't have MSG, does it?" The waiter shook his head no and departed with our orders. "Doctor's orders," I added to Rodrigo, who shot back a sympathetic look. We continued our conversation as follows:

\section{III}

Rodrigo Explains Why Law Is Not the Solution, AND Why We Need a Due Process of Legal STORYTELLING

"I do have a solution," Rodrigo replied, "but unfortunately it does not include law. At first, I thought it might. After all, one does not need einpathy to file a lawsuit. A judge does not need it to rule on technical inotions, or to see whether a complaint satisfies the elements of a statutory cause of action. Many of these acts are inechamical, requiring no large ainount of judgment. In fact, some Race-Crits have advocated the formality of the court setting as a positive advantage over nonformal dispute resolution, such as mediation, for cases presenting an imbalance of power, as most civil rights cases do. ${ }^{85}$ Unfortunately, I think litigation is not a very promising avenue of relief for society's poorest, inost disadvantaged classes."

"We talked in a general way about soine of these things before," I recalled. "I think it was the fourth time we inet." 86

"Your meinory is good, Professor. We are not the only ones to question faith in law as an instrument of social reform. There are many others, both on the left and on the right. ${ }^{87}$ But some think things would be better if only we had more einpathic judges, or ones with wider experience. ${ }^{88}$ Soine think things would be better if lawyers just learned to tell better, more vivid, stories in their pleadings, for example." 89

"But you think this would not help at all?" I said, a little dubiously.

"Less than we might hope," Rodrigo rephied. "Law is structurally biased against any display of empathy."

85. See Patricia J. Williams, The Alchemy of Race and Righrs 146-48 (1991); Richard Delgado et al, Fairness and Formality: Minimizing the Risk of Prejudice in Alternative Dispute Resolution, 1985 WIS. L. REv. 1359; Trina Grillo, The Mediation Alternative: Process Dangers for Women, 100 YALE L.J. 1545 (1991).

86. Delgado, Fourth Chronicle, supra note 1, at 1139-59; see also Delgado, Ninth Chronicle, supra note 1 (observing that law is useful mainly in an instrumental sense).

87. See Richard Delgado, Enormous Anomaly? Left-Right Parallels in Recent Writing About Race, 91 Colum. L. Rev. 1547 (1991) (book review).

88. See Henderson, supra note 25.

89. See Herbert A. Eastman, Speaking Truth to Power: The Language of Civil Rights Litigators, 104 Y ALE L.J. 763 (1995); cf. Ward, supra note 25, at 944 (criticizing this view as utopian). 
"Is that because of your Inquispro example?"90 I asked. "Namely, because we do not really want law to be uniform and nonracist, treating everyone alike. We want it to promote class advantage. If it didn't we'd change the system back."

"That's part of it," Rodrigo replied. "But there's more. Even perfectly unbiased judges, ones like Inquispro who treat blacks and whites absolutely alike, would end up doimg very little good. Incidentally, I think this is even more true for lawyers but we'll come back to that later. Let's focus on law at the more systemic level."

"Go ahead. I'm all ears," I said. "Why can't law redress the injuries of society's nost needy and oppressed? What about the Brown decision and times like the sixties? Then, courts were in the forefront of the social revolution: handing down decrees protecting civil rights protesters, desegregating schools and luncli counters, requiring due process in school disciplinary cases, and so on."

"True," Rodrigo conceded. "Unfortunately, that was an aberration. Most of the time, courts are no more kindly disposed to us and our causes than they are to any other group, perhaps even less so." 11

"And I assume you have a theory for why this is so?"

"I do-actually a group of explanations, corresponding to the different roles of judges, lawyers, and litigation as a whole."

\section{A. Rodrigo Explains Why Civil Rights Litigants Cannot Command the Empathy They Should - There Is No Due Process of Storytelling}

\section{The Litigants Themselves}

'Let's take the litigants first," Rodrigo began. "Let's say you are a plaintiff who has suffered a civil rights injury, maybe a black undergraduate or nember of a family injured by hate speech. You file suit, but soon find out that it is very hard to tell your story in court. The legal system requires that you tell a different narrative from the one that happened. Law slices up your narrative into little bits, into unfamiliar pieces. The pleading rules require a 'short and plain statement' of your claim, with eacli allegation being 'sinple, concise, and direct. ${ }^{92}$ The law does contain master narratives corresponding fairly closely to commercial grievances, to what industrialists want to say about each other in antitrust cases for example. ${ }^{93} \mathrm{But}$ it contains few narratives that seem written to remedy mjuries to less

90. See supra notes 19-25 and accompanying text.

91. See, e.g., Richard Delgado \& Jean Stefancic, The Social Construction of Brown v. Board of Education: Law Reform and the Reconstructive Paradox, 36 WM. \& MARY L. REv. 547, 549-67 (1995) (describing the Court's zigs and zags and minority interests' changing fortunes).

92. FED. R. CIV. P. 8(e)(1).

93. See, e.g., 2-2C Jay E. Grenig, West's Federal Forms: District Courts, Crvil chs. 28-34 (4th ed. 1994) for a treatment of pleading rules and requirements in federal court. 
entrenched interests. There is no pleading form for 'You treated me unfairly.' Thus, when a plamtiff starts to tell her story that her husband beat her for ten years, we interrupt and say, 'Don't tell us that story, tell us about imminent threats of death or violent imjury. What was your husband about to do to you when you killed him?'94 This focus on the immmence of the harm impairs the court's understanding of the totality of the harmful relationship. If it turns out the woman has nothing to tell of the official kind of story, we tell her to keep quiet. She had no story after all."

"So the law requires her to tell a stylized story that might or might not correspond to the injury she sustained."

"It can be even worse than that," Rodrigo continued. "Sometimes the law requires you to tell the other story - the perpetrator's, not your own. ${ }^{95}$ For example, in a civil rights complaint, you will end up having to tell and prove to the court that the other side acted intentionally."

"That's Washington v. Davis,"96 I imterjected. "The civil rights plaimtiff has to prove that the defendant's conduct was intentionally discriminatory, not inerely that it had a differential impact on persons like the plaintiff." 97

"Precisely," Rodrigo shot back. "And not only that, but the plaintiff has to prove tight chains of causation between what the defendant did and his or her injury."98

"And probably that the defendant had no legitimate busmess reason for denying the plaintiff a job or promotion," case does seem to concern the defendant, not the plaintiff, who, after all, is the one who suffered the injury."

"Exactly. Consider the hate-speech case we mentioned a mimute ago. The defendant, let's say, has burned a cross on the family's lawn. ${ }^{100}$ Or a group of fraternity kids shouts, 'Nigger, go back to Africa; you don't belong on this campus,' to an eighteen-year-old black undergraduate. ${ }^{101}$ If this case goes to court, the defendant immediately turns it into a First

94. Self-defense is generally only available if the threat is severe and imminent. SANFORD H. Kadish, et al., Criminal Law and Its Processes: Cases and Materiats (4th ed. 1983). See also Lucie E. White, Subordination, Rhetorical Survival Skills, and Sunday Shoes: Notes on the Hearing of Mrs. G., 38 BuFf. L. REv. 1, 19-52 (1990) (describing the difficulty one welfare recipient faced telling her story at a benefits hearing).

95. See infra notes $100-106$ and accompanying text.

96. 426 U.S. 229 (1976).

97. Id. at $238-48$.

98. On causation in civil rights cases, see, e.g., City of Richmond v. J.A. Croson Co., 488 U.S. 469, 493-511 (1989); Daniels v. Williams, 474 U.S. 327, 329-36 (1986); Firefighters Local Union No. 1784 v. Stotts, 467 U.S. 561, 578-83 (1984); Bell, supra note 83, at 170-73.

99. On the role of the "BFOQ," (bona fide occupational qualification) in civil rights law, see, e.g., Mack A. Player, Employment Discrimination Law § 5.29, at 280-95 (student ed. 1988).

100. R.A.V. v. City of St. Paul, 505 U.S. 377 (1992).

101. For a review of this and similar incidents justifying anti-hate speech rules, see Richard Delgado, Campus Antiracism Rules: Constitutional Narratives in Collision, 85 Nw. U. L. Rev. 343, 348-58 (1991). 
Amendment issue. The case will turn on whether he or she had a right to burn the cross or yell the epithet. You, who were merely walking home from the library late at night, or trying to sleep in your room at home, will find yourself on the defensive, depicted as someone who was trying to take away the precious free-speech rights of the skinhead or bigot."102

"Indeed," I said. "We both know abridgments of the First Amendment are a dangerous precedent if more voices are to be heard in our society. Yet we know how hate speech tends to silence and decrease the exchange of ideas, and how not all categories of speech are equally deserving of protection." 103 I paused nomentarily, and glanced around the restaurant. "I see what you niean by the narratives all being agamst you. In fact, I was just re-reading Scalia's opinion in the St. Paul cross-burning case the other day. He hardly mentions the family at all. They were an abstraction, almost entirely missing from the opinion, which concerns speech categories, the dangers of censorship, and what Scalia calls' 'viewpoint discrimination." "104

"A more perfect irony could not be imagined," Rodrigo continued. "The Jones family, who awoke to find a cross burning on their lawn, and the city that intervened on their behalf, considered guilty of discrimination!"

I paused for a monient while the waiter set down our food, a vegetarian stir fry for me and chicken in a lime-coconut curry for Rodrigo. "Looks fantastic," Rodrigo said, thanking our server.

"So," I summarized, "the plaintiff often does not get to tell her story at all. Even when she does, it's rarely the one the plaintiff naturally would tell. She cannot 'go back to the beginning.' She often finds that things she thought vital to the claim are irrelevant and cannot be told. The court interrupts, makes her tell her story in little slices, in response to direct examination. The other side gets to object every thirty seconds. Most of the 'material elements' concern the defendant and what she did. It's only when we get to the issue of damages that the plaintiff really gets to tell about herself and about what happened to her. The law makes one take what Alan Freeman calls the perpetrator perspective. Have I caught your meaning?"

102. On this ironic juxtaposition, see Charles R. Lawrence III, Crossburning and the Sound of Silence: Antisubordination Theory and the First Amendment, 37 VILL. L. REv. 787, 803-04 (1992) ("If First Amendment doctrine and theory is to truly serve First Amendment ideals, it must recognize the injury done by the private suppression of speech ...."); see also Mari J. Matsuda, Public Response to Racist Speech: Considering the Victim's Story, 87 MrcH. L. Rev. 2320, 2326-41 (1989) (describing injuries of victims of hate speech, injuries of which the law often fails to take account).

I03. See Richard Delgado, Words That Wound: A Tort Action for Racial Insults, Epithets, and Name Calling, in Mari J. Matsuda, et AL., Words That Wound: Critical Race Theory, AsSAULTIVe SPEECH, AND THE FIRST AMENDMENT I22-33 (1993) (discussing silencing effect of hate speech and noting that the First Amendment protects some forms of speech-for example, social vituperation-but not others such as libel, official secrets, fighting words, and disrespectful words uttered to a judge or other authority figure).

104. R.A.V., 505 U.S. 377; Lawrence, supra note 102, at 788-9I. 
"You have."

"It does sound dire," I said. "But surely, Rodrigo, there have to be some limits on storytelling, as you call it. Otherwise, trials would be interminable. Pleading rules exist for good reason. Without them, anyone could go to court and enter any old generalized grievance against anyone else."

"True," Rodrigo replied. "But law makes our types of grievances particularly difficult to bring."

"Then maybe the solution is to litigate more, not less-to get the law to recognize new causes of action. Then it would become possible to tell new narratives, as happened with the tort of intentional infliction of emotional distress, for example. ${ }^{105}$ It took time for the legal system to recogmize sexual harassment of women in the workplace. Before Catharine MacKinnon's path-breaking work, women could not tell those stories in court. $^{106}$ Today they can. Maybe our people will eventually be able to tell their stories."

"I doubt it," Rodrigo replied gloomily. "The courts' and the country's mood is all $\mathrm{m}$ the other direction. American society is impatient with what they call 'activist judges.' 107 We believe the rights revolution has gone too far. Affirmative action is under attack. ${ }^{108}$ The dommant narratives of the sixties and seventies have shifted back toward a traditional and morally conservative posture. In the sixties, African Americans were long-suffering victims or righteous warriors. Then, the images changed to those of terrifying gangsters and Black Power advocates. ${ }^{109}$ In the last decade, we've had the Willie Hortons and Cadillac-owning lazy welfare cheat, the affirmative action hire who lacks 'traditional merit criteria' and blocks the promotion of a supposedly more deserving white."110

"So it is in the hate-speech debate," I said, returning to Rodrigo's previous example. "There, the narrative of harm is given short shrift, even though quite provable. ${ }^{111}$ Courts and commentators quickly substitute the

105. See, e.g., W. Page Keeton et al., Prosser \& Keeton on the LaW of Torts $\$ 12$ at 54-56 (5th ed. 1984) (on the comparatively recent recognition of this tort); Regina Austin, Employer Abuse, Worker Resistance, and the Tort of Intentional Infliction of Emotional Distress, 41 STAN. L. REv. 1 (1988).

106. See Catharine A. MacKinnon, Sexual Harassment of Working Women: A Case of Sex DisCRIMINATION (1979).

107. E.g., Robert F. Nagel, Constitutional Cultures: The Mentaltty and Consequences of Judicial Review (1989).

108. See supra notes 58,68 and accompanying text.

109. On popular images of African Americans and other minorities of color, see Delgado \& Stefancic, supra note 25, at 1262-75; see also Richard Delgado, Storytelling for Oppositionists and Others: A Plea for Narrative, 87 Mrch. L. REv. 2411, 2437-41 (1989) (arguing that "counterstories" have the potential to change complacent majority narratives despite the difficulty of conveying them in court).

110. See Delgado \& Stefancic, supra note 25 , at $1262-67,1290$ n.221.

111. See Richard Delgado, Words That Wound: A Tort Action for Racial Insults, Epithets, and Name-Calling, 17 HaRv. C.R.-C.L. L. REv. 133 (1982) (describing how racist, assaultive speech injures its victims). 
wholly unproven narrative of censorship, as though every campus that enacts a mild hate-speech rule will immediately turn into an Orwellian nightmare with Big Brother looking over everyone's shoulder. ${ }^{112}$ This is quite speculative, and, in my opinion, extremely unlikely. Or take another narrative, the chilling effect that speakers are said to suffer if any speechliniting code, like a hate-speech rule, is put into place. Set that alongside the terror, demoralization, and high dropout rates that are provably associated with campus hate speech, as dozens of studies show. ${ }^{113}$ Which one is more demonstrable? One finds that all the prevailing narratives enable elite and not-so-elite whites to do what they are accustomed to doing, and then defend it in court. They have all these narratives going for them: Big Brother, the state as censor, the terrified speaker just waiting to be chilled, and the thin-skinned hypersensitive black just waiting to run to the authorities instead of shrugging it off."

I sat back. "I'In beginning to see why you have little faith in the legal system to solve our empathy crisis. Still, earnest, impassioned talking sometimes works. What about Brown v. Board of Education ? ${ }^{114}$ And what about your own success in talking your way out of trouble with your captors. Did you not succeed in getting them to empathize with you?"

"We were about the same age and political orientation. They let me talk without interruption. Actually, I talked a blue streak for fifteen minutes, afraid for my life. Plus, I had something they wanted, namely that I would go away without making trouble."

"They afforded you full due process of storytelling. In that respect, your situation was not parallel with the one that prevails in most courts."

"Not at all. But several other features reduce the possibility of empathy in that situation," Rodrigo contimued. "Not only do we make it difficult for plaintiffs to tell their story. Consider how we treat witnesses."

\section{Witnesses}

"You're going to say rudely, I bet. I've just been reading about a famous criminal trial where many witnesses got raked over the coals and left the courtroom feeling impugned and nualigned, even though they were just trying to do their job, namely, to tell what they saw."115

"Exactly," Rodrigo replied. "Let's say the plaintiff tries to bring in some friends to help him tell his story. These are people who know some-

112. E.g., Henry L. Gates, JR. et al., Speaking of Race, Speaking of Sex: Hate Speech, Civil Rughts, AND CiviL LiberTiEs (1994) (depicting in often terrifying fashion the parade of horribles likely to ensue if hate-speech rules are enacted).

113. See The Price We Pay: The Case Agannst Ractst Speech, Hate Propoganda and PorNOGRAPHY (L. Lederer \& Richard Delgado eds., 1995) (containing empirical studies and first-person aecounts).

114. 347 U.S. 483 (1954).

115. On the harsh treatment of witnesses in the recent murder trial of O.J. Simpson, see, e.g., Circus in the Courtroom (Editorial), Bourder, CO, Daily CAMERA, Apr. 26, 1995, at 2-C. 
thing about the event that gave rise to the lawsuit, say, the act of discrimination. The witness soon learns that in our legal culture it is okay to treat witnesses with suspicion and contempt. The other side gets to badger them, imply they might be lying, insinuate all sorts of unsavory motives."116

"Yet we insist that everyone treat the lawyers and judge with the greatest respect. Anyone who stood up in court and said that the prosecutor or judge might be lying or biased would be treated as having done soinething scandalous. Yet we do this sort of thing with plaintiffs' witnesses routinely."

"And with women who bring charges of rape,"117 Rodrigo added.

"In the courtrooin, certain types of emotional display will get you a contempt citation; others will not. Judges can shout, interrupt, and show exasperation or disbelief. But the plaintiff, her attorney, and the witnesses are expected to be models of decorum."

"Emotional rules are the underside of power and ideology," Rodrigo said. "It's okay for an empowered actor, say, your boss, to be angry at you. But you may not show anger at your boss. ${ }^{118}$ It's the same way in court. There is always a power imbalance visible in courtroom interaction, conveyed in who speaks first, who interrupts, and wlio gets to paraphrase and sum up at the end."

"It's true," I said, taking the devil's advocate position, "that plaintiffs and witnesses find their roles limited in court by rules of evidence, relevancy, cross-examination, and so on. But that's the way things are in an adversary system. There have to be some rules, or else it would be a freefor-all and things would be even worse for what you call disempowered litigants. Aren't you forgetting that every plaintiff has a perfect counterbalance to all this power and cumbersome machinery that is deployed against him in court, namely the attorney, a gladiator trained to negotiate the maze of court rules, professionally and ethically bound to represent the client to the best of her ability. Doesn't the lawyer cancel all or most of that power mibalance out?"

116. Id.; see also Sharon E. Caims, A Proposal for Critical Research on Emotional Expression and Display Rules in the American Courtroom (1995) (unpublished manuscript, on file with author) (describing how discourse rules govern shows of emotion).

117. On the reform of rape law, see SUSAN Estrich, REAL RAPE (1987).

118. For studies of these unwritten rules of etiquette and practice in lawyer-client relations, scc Bryna Bogoch, Power, Distance and Solidarity: Models of Professional-Client Interaction in an Israeli Legal Aid Setting, 5 Discourse \& Soc'y 65, 76 (1994) (observing that client expressions of emotion are "frowned upon" in lawyer-client interactions: "[T]he lawyer challenges the legal relevance of the client's emotional objectives. [The lawyer's] goals are the ones that count, because in [the] traditional style of lawyer-client interaction it is the lawyer who determines what is relevant.'); Bryna Bogoch \& Brenda Danet, Challenge and Control in Lawyer-Client Interaction: A Case Study in an Israeli Legal Aid Office, 4 TExT 249 (1984) (describing how lawyers assume and convey a superior social and intellectual status through language); Caims, supra note 116. 


\section{The Lawyer}

"I wish it were that way," Rodrigo said with a sigh. "But a lawyer's training and culture disincline him or her to challenge the narrative structures we just inentioned. Lawyers who spoke up, or mimicked the emotional tone of the judge, would be sanctioned or disbarred. ${ }^{119}$ Lawyers cannot depart much froin the stylized, desiccated stories spelled out in the rules of pleading. Gabel and Harris proposed different standards for lawyers representing political clients, ${ }^{120}$ but they were virtually the only ones who did. Recent clinical literature contains articles showing that even famous radical lawyers iniss opportunities to tell their clients' stories. Instead, they settle for the dry, cautious tone set out in the pleading books and encouraged by the prevailing ethos, the bland decorousness of the courtroom." 121

"Even public interest lawyers litigating civil rights cases are prone to place the chent's story second to their own," I added. "I'm reininded of the article you mentioned, in which Derrick Bell points out how civil rights attorneys end up litigating one thing when their clients really want another."122

"It's not necessarily that the lawyer has a superficial understanding of the poor, black client. Rather, it's that he believes he knows best. He believes he has to collaborate with the court by retelling the client's story so that it coines out in the sanitized, approved version. And since most lawyers are white, male, and middle-class, this can be a real problein. If the lawyer's experience, background, and history are radically different froin those of the client, the lawyer can easily dismiss the client's real objective and substitute his own. Lawyers may know the client's misery and understand fully the story he or she wants and needs to tell. But too often the lawyer puts the law story, the familiar one, the one he was trained to tell, first. The lawyer is trained to operate within the system."123

119. See Peter Gabel \& Paul Harris, Building Power and Breaking Images: Critical Legal Theory and the Practice of Law, 11 N.Y.U. Rev. L. \& Soc. Change 369, 399-405 (1982-83) (arguing that lawyers must cballenge the sanctity and political hierarchy of the courtroom to effect change in a broader social context).

120. Id. The authors also propose an expanded concept of what constitutes a "political case." Id. at $395-99$.

121. See Eastman, supra note 89 , at $765-72,777-81$.

122. Bell, supra note 34, at 470-72, 482-93; see also Anthony V. Alfieri, Practicing Community, 107 Harv. L. Rev. 1747, 1751 (1994) (book review); Book Note, White Knight, 108 HaRv. L. Rev. 959, 962-64 (1995) (reviewing JACK Greenberg, Crusaders in the Courts: How A Dedicated BAND OF LAWYERS FOUGHT FOR THE CIVIL RightS Revolution (1994)) (arguing that, in certain contexts, minorities can more effectively represent the interests of civil rights organizations than can whites). "When the time arrives that a non-minority can just as effectively represent the interests of minorities as the leader of a civil rights organization, the time will have arrived when civil rights organizations are no longer needed." Id. at 964.

123. See Eastman, supra note 89, at 765-72; see also Martha Minow, Partial Justice: Law and Minorities, in THE Fate of LAw 15, 68-77 (Austin Sarat \& Thomas Kearns eds., 1991) (discussing effaccment of minorities through the choice of story); infra notes $135-43$ and accompanying text. 
I remembered something I had just read. "Rodrigo, you have some empirical evidence on your side. I was reading Paul Finkelınan's review of a book by J. Clay Smith on the history of black lawyers in America. ${ }^{124}$ Finkelman commented on how few lawyers, black or white, were in the forefront of the civil rights movement. ${ }^{125}$ All the great leaders were nonlawyers: Martin Luther King, W.E.B. Du Bois, Frederick Douglass, Malcolm X, Jesse Jackson. ${ }^{126}$ They were historians, or teachers, or ministers; very few were lawyers. Do you think that's because a people in trouble know mstinctively a lawyer is not the one to tell its story as they need to have it heard? Or is it that lawyers shy away from leadership roles in social movements, preferring to remain in the background and conduct negotiations, file for injunctions, and do the nitty-gritty work that allows the real leaders to operate effectively and stay out of jail?"

"It may be both," Rodrigo replied. "Soine lawyers do propose useful things. Thurgood Marshall and the other lawyers in the NAACP Legal Defense Fund certainly did, which Finkelman of course acknowledges. ${ }^{127}$ But the further removed a lawyer is by experience and background froin the group represented, the less effective he or she seems to be. No white male middle-class lawyer advocated attention to racial slurs and hate speech until a minority lawyer did. ${ }^{128}$ Catharine MacKinnon, not a middle-class white male, proposed the elimination of sexual-history testimony in rape cases and developed a new cause of action for sexual harassment in the workplace. ${ }^{129}$ No white male-except that genius, Alan Freeman-proposed the idea that civil rights law, that jewel in the crown of our jurisprudence, systenratically disadvantages its very beneficiaries: minorities. ${ }^{130}$ The Supreme Court sees no serious problein with capital punishment that falls disproportionately on minorities. ${ }^{131}$ And so on."

"I'm sure you know you are ignoring a few notable exceptions, like Jack Greenberg," I said. "But as a generalization, you may be right. Why do you think that is?" I asked.

"I think there is something fundamentally wrong with the legal narrative: one siniply cannot tell stories of nrany kinds of injustice through the

124. Paul Finkelman, Not Only the Judges' Robes Were Black: African-American Lawyers as Social Engineers, 47 Stan. L. Rev. 161 (1994) (reviewing J. Clay Smith, JR., Emancipation: The MAKING OF THE BLACK LAWYER, 1844-1944 (1993)).

125. Id. at 189.

126. Id. at 189-92.

127. Id. at 168-69.

128. See Delgado, supra note 111 (arguing for recognition of a new tort for racist speech).

129. See MacKinNon, supra note 106.

130. See Alan D. Freeman, Legitimizing Racial Discrimination Through Antidiscrimination Law: A Critical Review of Supreme Court Doctrine, 62 MinN. L. Rev. 1049 (1978).

131. See McCleskey v. Kemp, 481 U.S. 279 (1987); see also Randall L. Kennedy, McCleskey v. Kemp: Race, Capital Punishment, and the Supreme Court, 101 HARv. L. Rev. 1388 (1988). Kennedy emphasizes "the unfaimess that race-of-the-victim discrimination visits upon the black community by denying equal treatment with respect to those who kill its members." Id. at 1391. 
law. And if one's training is in the law, one has virtually de-trained oneself to represent society's outcasts. It takes a superhuman effort to be an empathic human being. To be both a lawyer and an empathic human is practically impossible. Our review of civil rights history shows that the legal narrative is less effective at promoting social change than that of practically any other profession, such as teaching, the ministry, or street-level activism, for that matter. Most of your Crit friends think so, too."132

"That they do. And, at the day-to-day level, the rules of courtroom etiquette require that one speak within the legal paradigm and not use emotional discourse, that one adhere to rules of evidence that carve one's narrative into little pieces and destroy its momentum and integrity. ${ }^{133}$ Lawyers are trained to observe these rules until they become second nature. We are trained not to empathize but to be technocrats, concentrating on the small, not the big, picture. We focus on motions and pleadings, not stories, much less things like injustice, love, and coinpassion. The lawyer ends up telling his story, not the client's."

"We do allow victinl-inpact statennents,"134 Rodrigo mused. "That's one kind of new story we do like."

"We find it easy to empathize with the victims of crime," I said, "particularly if they are middle-class people like us."

"Even better, victims are not required to testify through a lawyer. They can speak for theinselves. When we want someone to speak really effectively - that is, to help society condemn the criminal even inore roundly - we let them speak uninterrupted. We could do the same for civil rights plaimtiffs, but don't."

"But, Rodrigo," I interjected, "there is a whole new literature on effective lawyering. ${ }^{135}$ It is being written by clinical faculty, some at the best

132. On the limitations of liberalism in effecting racial reform, see, e.g., Davis, supra note 74; Delgado, Chronicle, supra note 1; Delgado \& Stefancic, supra note 25.

133. See White, supra note 94 , at 43 ; supra notes $92-95$ and accompanying text; see also Gabel \& Harris, supra note 119 (advocating challenge to and destruction of this paradigm to advance social goals); cf. KurN, supra note 53 (arguing that science advances only through reinterpretation of the dominant paradigm).

134. For a discussion of a recent case dealing with victim-impact statements, sce David D. Friedman, Should the Characteristics of Victims and Criminals Count?: Payne v. Tennessce and Two Views of Efficient Punishment, 34 B.C. L. Rev. 731 (1993) (analyzing Payne v. Tennessee, 501 U.S. 808 (1989)).

135. See Anthony V. Alfieri, Stances, 77 Cornerr L. Rev. 1233 (1992) (reviewing the "effective lawyering" literature). 
schools. Writers like Menkel-Meadow, ${ }^{136}$ López, $^{137}$ Cunningham, ${ }^{138}$ Alfieri, ${ }^{139}$ and others are writing about client narratives. They are writing about the need to listen more carefully, to translate better, to get inside our clients' heads. ${ }^{140}$ They are warning about the dangers Derrick Bell first raised, of putting the law and the lawyer's objective first. ${ }^{141}$ Do you not think things are changing for the better?"

"I would like to think so," Rodrigo answered. "But a lawyer cannot easily escape the confines of his or her background, culture, and professional disciplime. Herb Eastman shows that even top lawyers, like the late William Kunstler, tell dull, lifeless, stereotyped stories, at least at times. ${ }^{142}$ And Anthony Alfieri, one of the best of the young climicians, confesses that he often falls short im empowering his clients and letting their voices and

136. E.g., Carrie Menkel-Meadow, Portia in a Different Voice: Speculations on a Women's Lawyering Process, 1 BeRKELEY WOMEN's L.J. 39 (1985) (exploring the sameness-difference debate and the addition of women's voices to the Icgal profession); Carrie Mcnkel-Meadow, Is Altruisnt Possible in Lawyering? $8 \mathrm{GA}$. ST. U. L. REv. 385 (1992) (noting the suppression of altruism and care for others in the legal system). Menkel-Meadow concludes, howevcr, that altruistic behavior can be promoted in legal edueation:

I believe that with a focus on empathy training through perspective-taking, role-playing, simulation, and other forms of less conventional legal education, we can actually increase lawyers' awareness that they live in the world with other people who often have needs as legitimate or even more legitimate than those of lawyers or their clients.

Id. at 417 (footnote omitted). On the potential difficulties of such a process, see supra notes 32-47, 6672 , and accompanying text (discussing faise empathy).

137. E.g., López, supra note 43; Gerald P. López, Reconceiving Civil Rights Practice: Seven Weeks in the Life of a Rebellious Collaboration. 77 GEo. L.J. 1603 (1989); Gerald P. López, Training Future Lawyers to Work with the Politically and Socially Subordinated: Anti-Generic Legal Education, 91 W. VA. L. REV. 305 (1989).

138. E.g., Clark D. Cunningham, A Tale of Two Clients: Thinking about Law as Language, 87 Mich. L. Rev. 2459 (1989) (recounting the author's experience as a lawyer and telling of the difficulty in faithfully translating a client's story); Cunningham, supra note 51.

139. E.g., Anthony V. Alfieri, Reconstructive Poverty Law Practice: Learning Lessons of Client Narrative, 100 YALE L.J. 2107 (1991) [hereinafter Alfieri, Reconstructive] (arguing that poverty lawyers must create a new interpretive narrative to integrate client narratives into legal storytclling); Alfieri, supra note 122; Anthony V. Alfieri, The Ethics of Violence: Necessity, Excess, and Opposition, 94 Colum. L. Rev. 1721, 1750 (1994) (book review essay) (noting that "violence is frequently submerged in the daily motions of law, legal institutions, and lawyers"); White Knight, supra note 122.

140. E.g., Alfieri, Reconstructive, supra note 139; Binny Miller, Give Them Back Their Lives: Recognizing Client Narrative in Case Theory, 93 Mrch. L. REv. 485 (1994); White, supra note 94.

141. See Bell, supra note 34. On suggestions that lawyers afford clients a larger role in selecting a case theory, see Miller, supra note 140 , or in telling their own stories in court or in the law reviews, see, e.g., Cunningham, supra note 51, at 1326-28, 1357, 1383-84. But see White, supra note 94, at 32-33 (describing how the author, providing legal representation for a poor black client, felt the need to position herself with the client to overcome "a complex pattern of social, economic, and cultural forces [that] underwrote the procedural formalities, repressing and devaluing [the client's] voice").

142. Eastman, supra note 89, at 778-81. 
personalities shine through. ${ }^{143} \mathrm{He}$ goes on at great length about how he erased the pain and identity of one of his clients, a certain Mrs. Field."144

"I read that article," I replied. "And even though his inea culpa is drawn out over several pages, I kept wondering: did he ever really understand Mrs. Field? He recounts how his client, a Social Security applicant who sought relief because she lost her job due to an inability to read, finally broke down and wept. ${ }^{145}$ The woinan was undoubtedly frustrated-the judge refused to believe she could not read enough to hold a job-and Alfieri was forced to demonstrate graphically to the court that she could not read, by holding up various signs and charts. ${ }^{146}$ But Alfieri read inore into it than that; he believed the woinan was frustrated at being unable to tell her story of segregated classrooms and growing up in a house without many books."147

"I see what you mean," Rodrigo said. "Alfieri, although a fine lawyer and progressive scholar, was reacting to her life experience as though he lad lived through it; in his imagination he was a black-white. And for him, an educated, sensitive person, growing up in an environment without books and being relegated to underfunded schools would have been intolerable. Mrs. Field, though, miglit have been quite happy witl her all-black scliools, as Bell reminds us. ${ }^{148}$ And whether she experienced the lack of books in her parents' house as a deprivation, even we have no way of knowing. She did experience the cut-off of Social Security benefits as a harsh deprivation; that we know. The author seenns almost as concerned with where he fit in as with his client's own expressed desires, namely, for Social Security benefits."

"Progressive lawyers may go on and on about their consciences, ${ }^{149}$ etc., because they want empathy not for their clients, but for theinselves. They lose all their cases. Their clients sometimes lie to them. The judges are rude. Often their clients want $\mathrm{X}$ when the lawyers want $\mathrm{Y}$-the grand declaration of principle, for example that segregated schools are always

143. Alfieri, Reconstructive, supra note 139, at 2128-29; Alfieri, Ethics of Violence, supra note 139, at 1721-44, 1749 (arguing that we must lcam, unlearn, and releam better or different approaches to our clients and advocacy); see Anthony V. Alfieri, Defending Racial Violence, 95 CoLum. L. REV. 1301, 1305-06 (1995) (arguing that lawyers must struggle to surmount the settled expectations and dominant narratives associated with their roles).

144. Alfieri, Ethics of Violence, supra note 139, at 1721-25, 1729, 1733-36, 1749-50; see also Alfieri, Reconstructive, supra note 139, at 2130 (providing another mea culpa about a different client, Mrs. Celeste).

145. Alfieri, Ethics of Violence, supra note 139, at 1724.

146. Id.

147. Id. at $1731-33,1743,1748$.

148. See Bell, supra note 34 , at $470-72,482-93$.

149. For other self-fiagellations and confessions of failure, see Cunningham, supra note 51, at 1299 ("I was one of his oppressors. I was his lawyer."); id. at 1325-26, 1330; Miller, supra note 140, at 56972; White, supra note 94 , at $45-50$. 
bad-as we mentioned before. ${ }^{150}$ In the end, liberal empathy is often false, misdirected, or solipsistic."

The waiter, who had materialized at our table side while we were talking, asked us if we cared for dessert. I looked at Rodrigo who shrugged back, a little eagerly, I thought. What the heck, I thought, I'll go running tomorrow.

"Could we see your dessert tray?" I asked the waiter. He disappeared, taking our empty dinner plates with him. I picked up our conversation. "But you mentioned that there is another way in which litigation prevents people from telling their stories."

\section{The Court System}

"Oh, yes," Rodrigo replied. "Law disaggregates and atoinizes, treating as separate many grievances that have a group dimension. ${ }^{151}$ This leaves the litigant lonely and without allies. It encourages him or her to think about his own grievance, not those of the group."

"I can think of a few ways it does this," I chimed in. "Doctrines of standing and real party in interest limit who can sue or be sued. ${ }^{152}$ While joinder is possible to a degree, and class actions are possible in some situations ...."

"Although we both know how the federal courts have been cutting back on the class action vehicle in recent years,"153 Rodrigo interjected. "They insist on satisfaction of the mimimum amount in controversy for every plaintiff, ${ }^{154}$ for example, and require notice to all class members who are identifiable through reasonable effort. ${ }^{155}$ These make group redressout of whicl a group story may grow-difficult."

"True. But there are other features that render courts unattractive to social reformers. Courts are bound by precedent, which may contain bad stories. If the only narrative law recognizes is a bad one-one that requires that you demean yourself or tell your story in a strange and contorted way,

150. See supra notes 34-35 and accompanying text; see also Miller, supra note 140, at 569-71 (describing how lawyer wanted a client of color to adopt a theory of racism in defending against a shoplifting charge; client rejccted this theory); White, supra note 94, at 46-52 (recounting how lawyer had scripted a client's testimony and suggested that the client "play the victim if she wanted to win").

151. See, e.g., Delgado \& Stefancic, supra note 91, at 550-51, 559, 562 (arguing that because of law's narrow scope, change in a legal rule leaves unchanged interrelated social structures); Grillo, supra note 85 , at 1550 (arguing that mediation may disempower by atomizing, especially for individuals, such as women, with a relational sense of self); see also Richard Delgado, Stark Karst, 93 Mich. L. Rev. 1460 (1995) (book review).

152. See Laurence H. Tribe, American Constitutional Law \$§ 3-10, 3-11, 3-14 (2d ed. 1988).

153. See Charles A. Wright, Law of Federal Courts $\S 72$, at 513-25 (5th ed. 1994).

154. Zahn v. International Paper Co., 414 U.S. 291 (1973). Several district courts and one circuit court have held that the supplemental jurisdiction provision in the Judicial Improvements Act of 1990, Pub. L. No. 101-650 § 310(a), 104 Stat. 5113 (codified as 28 U.S.C. § 1367), overruled Zahn. See, e.g., Frce v. Abbott Labs., 51 F.3d 524, 525, 527-29 (5th Cir. 1995); see also WriGHT, supra note 153, at 523.

155. See, e.g., Eisen v. Carlisle \& Jacquelin, 417 U.S. 156 (1974). 
or jump through very high hoops even to be heard at all-you will not choose to tell your story there very often. Judges' experiences and life perspectives are those of a certain class. There are very few African American, lesbian, or disabled judges, or ones from a working-class background. Since their experience is limited, judges may be ill-equipped to understand your plea. ${ }^{156}$ Rules relating to ripeness, mootness, and standing mean that the court can only consider the case before it, not the broad story of dashed hopes and centuries-long mistreatment that afflicts an entire people and forms the historical and cultural background of your complaint. ${ }^{157}$ And the decree, even if favorable, will fix only your story, not that of others, especially after recent cutbacks in res judicata law and the class action vehicle. ${ }^{158}$ In short, courts are ill-equipped to hear and act on the stories many in our society most urgently need to tell."

"Another way of putting it," Rodrigo said, summing up, "is what I'm thinking of calling the reconstructive paradox. ${ }^{159}$ It's an aspect of what you said just now. It begins by observing that the greater the evil-say, black or female subjugation - the more entrenched it will be. The more entrenclied any evil, the more massive the social effort that will be required to dislodge it. An entrenched social evil will be invisible to many-maybe most-in the culture, simply because it is embedded, entrenched, and ordinary-seeming. The massive social effort will inevitably collide with other social values, settled expectations, the way things are, and so on. It will entail dislocations, new priorities, and spending shifts. These latter efforts, civil rights marches, for example, or revisions in college curricula, will be highly visible, by contrast, and will spark resistance and opposition. One is apt to be characterized as 'Big Brother,' a fascist, a reverse racist, and so on. Resistance then will feel principled to the resister, because the other side will appear to be sacrificmg real liberty, real money for a nebulous and dubious social goal, like helping blacks."160

"Reconstruction and reform, then," I said gloomily, "will always seem unprincipled, premature, wrong, and will spark resistance-until one hun-

156. See Delgado \& Stefancic, supra note 91 , at 550-51 (discussing the way judges' background and mind-set limit the way they interpret and apply doctrine).

157. On the limits of judicial empathy, see Richard Delgado \& Jean Stefancic, Norms and Narratives: Can Judges Avoid Serious Moral Error?, 69 TEx. L. Rev. 1929 (1991) (advocating both judicial exposure to counter-narrative and additions to the law and literature canon).

158. See Martin v. Wilks, 490 U.S. 755 (1989) (partially overnuled by Civil Rights Act of 1991, Pub. L. No. 102-166, 105 Stat. 1071); see also Susan S. Grover, The Silenced Majority: Martin v. Wilks and the Legislative Response, 1992 U. ILL. L. Rev. 43.

159. See Delgado \& Stefancic, supra note 91, at 558-59 (coining term).

160. Id. at 558-60; see also Kimberlé W. Crenshaw, Race, Reform, and Retrenchment: Transformation and Legitimation in Antidiscrimination Law, 101 HARV. L. REv. 1331 (1988) (proposing that adoption of the legal voice both advances and impedes the cause of social transformation, because it legitimates the existing regime while permitting small, incremental adjustments); Richard Delgado, Shadowboxing: An Essay on Power, 77 CorNelL L. Rev. 813 (1992) (discussing the way the cultural template, or backdrop, against which legal acts take place dictates particular results). 
dred years later when consciousness changes, at which time we will look back and wonder how we possibly could have resisted that."

"Oh," Rodrigo exclaimed. "Here's the dessert tray!"

\section{IV}

IN Which Rodrigo OfFers a SOlution to the False-EMPathy Dilemma, and Suggests Two Roles For White Reformers aND FELLOW TRAVELERS

We picked out our desserts, which the waiter quickly brought, Rodrigo's a creamy French-Vietnamese pastry of soine sort, mine a tangy lemon sorbet. After eating for a few minutes in tacitly agreed-to silence, I looked up at Rodrigo.

"I hope that my real dessert will be that you tell me what your solution is to the predicament in which we find ourselves. Reformers and minorities get little if any genuine empathy in courts, or indeed anywhere, and can count on no one but themselves to climb out of poverty and despair." I remembered my own sense of desolation when I thought Rodrigo was gone forever. "Life's road is hard going. Can't we find confederates? If we can't look to our liberal friends, to whom can we turn?"

"Empathy would work in a just world, one in which everyone's experience and social histories were roughly the same, unmarked by radical inequality. In such a world, we would have things to trade. There would be reasons for needing to get to know others, for understanding what they feel and need. But, as we mentioned earlier, we don't live in such a world."

"And since we don't," I said, "what should we do? We can't give up, can't just sit around bemoaning our plight or plotting revolution. There inust be a strategy, a set of procedures for operating in an imperfect world."

"I do have a plan," Rodrigo said, drawing a deep breath. "It contains three provisions. It's all based on the idea that false empathy is worse than none at all, worse than indifference. It makes you over-confident, so that you can easily harm the intended beneficiary. ${ }^{161}$ You are apt to be paternalistic, thinking you know what the other really wants or needs. ${ }^{162}$ You can easily substitute your own goal for hers. You visualize what you would want if you were she, when your experiences are radically different, and your needs, too. ${ }^{163}$ You can end up thinking that race is no different from class, that blacks are just whites who happen not to have any money right now. You can think that middle-class blacks or ones with professional degrees have it made, need no solicitude or protection when their situation

161. See supra notes $47-54$ and accompanying text.

162. See supra notes $30-33,55-56,142-48$ and accompanying text.

163. See supra notes $30-34,55-56,150$ and accompanying text. 
is in some respects worse than that of the black who hives in an all-black, working-class neighborhood."164

"Your solution, Rodrigo, your solution," I urged.

"Oh-as I mentioned, I think the solution lies in three parts. The first is essentially to give up on, to forswear, the very idea of empathy as any sort of primary tool for our advancement. We must reahze that persons of radically different background and race cannot be made vicariously to identify with us to any significant extent. Their help, if any, is likely to be misguided, paternalistic, mistaken, and unhelpful. This is especially so if they are lawyers and other court officers. Legal empathy is even rarer and less trustworthy than other kinds. Law carves up your story, serves it up to an uncomprehending judge, atomizes your claim, and sparks real resistance when it tries to do something-as it does every century or so."

"And then what?"

"The next step-after abandoning hope in hiberal empathy and crossrace, cross-class identification-is to urge one of two strategies that I think will work. Would you like to hear them?

"Yes, yes," I said impatiently.

\section{A. Rodrigo's First Plan for Whites: The Race Traitor Idea}

"The first role for white folks who would like to be helpful is what Noel Ignatiev and John Garvey call the race traitor. ${ }^{165}$ Have you heard of the idea?"

I strained to remember. "I think I have. Don't they have a magazine by that title?"

"Yes," Rodrigo replied. "I brought you a copy. It's in that envelope back in your office. But I see you know about it already. Just when I think I have an idea or approach that will surprise you, it turns out you know about it already. It's kind of discouraging talking with you, Professor."

"Stop the flattery. You're miles ahead of me in most respects. I just have a hittle more experience than you. Tell me how you see the race traitor idea applying to our empathy dilemma."

"White people who want to help can become traitors to the white race. As Ignatiev and Garvey put it, 'Treason to whiteness is loyalty to humanity. ${ }^{166}$ For example, if a white person is in a group of whites and one of them tells a racist joke or story, the white can look up in surprise and say: ' $\mathrm{Oh}$, you inust have told that story in front of me because you assumed I am

164. See Ellis Cose, The Rage of a Privileged Class (1993). The middle- or upper-income person of color is apt to have more contacts with whites and thus more opportunities to be the victim of discrimination. Id.

165. See Treason, supra note 5; see also 3 RACE Tratror (Spring 1994); 4 RACE TRArToR (Winter 1995).

166. See, e.g., RACE TRAITOR, supra note 165 (front covers). 
white. I'm not. I'm black. I may look white, but my ancestry is black. And let me tell you why I found that story offensive."'167

"In other words," I said, "they identify with blacks radically and completely, not by imagining how they would feel if they were black, but by identifying themselves with blacks when other whites ask for their help in reinforcing white supremacy."

"Yes," Rodrigo contimued. "And that includes rejecting white privilege, so far as a white-looking person is capable of doing that. In dozens of encounters in life, one takes on the role of being, acting, and speaking out as though one were a black-that is, one of us." 168

"I'm not sure how that is possible," I said. "Could you give me an example?"

"Ignatiev and Garvey themselves give many. Whiteness is a social construct, basically a readimess to accept many privileges that come to you if you look and act a certain way. ${ }^{169}$ If you refuse to be white you begm the process of destabilizing this construction that society relies on to preserve the current system of racial subordination. So, suppose a neatly dressed white person, who happens to be a race traitor, is pulled over by a police officer and then let go with a warning. The person ought to question the officer, "Would you have done this if I had been black?"'170

"So whites ought to reject racial privilege and challenge manifestations of racism that they observe."

"Yes. And if enough people do this, the system will collapse, because whites will never be sure which other whites are confederates-are loyal to the white race in the sense of accepting unearned privilege and conspiring tacitly to keep blacks down. ${ }^{171}$ The race traitor not only opposes racism but seeks to disrupt its normal functioning, and does so from within. Therein lies the concept's power. The color line is not the work of a few racist individuals but of a system of institutions and practices. Race traitors challenge each of these at every turn: tracking in public schools; location of public housing on the other side of the tracks; so-called meritocratic criteria

167. See Treason, supra note 5, at 85 (explaining the goals and practices of the Race Traitor); see also Edward H. Peeples, Richmond Journal: Thirty Years in Black and While, 3 RACE TRATTOR 34, 45 (Spring 1994) (describing author's act of "racial sedition" in denying he was white, when confronted by a store clerk who insisted that he could not intend to buy the "colored newspaper").

168. Treason, supra note 5 at 84-85. Ignatiev explains that whites must be willing "to pay the dues, if necessary, to forgo the social advantages of being white, in order to achieve genuineness of expression." Id. at 85. White "crossover" behavior may entail some "ripping off" of black culture. "By itself," Ignatiev concludes, "crossover represents a potential for race treason, not the actuality." Id.; see also LOPEZ, supra note 43 , at $24,30-38,50-51,55,73$ (suggesting various measures by which activist lawyers can identify more fully with the client community); Alfieri, supra note 122, at 1762-63 (same).

169. See Treason, supra note 5, at 84 ("[S]o long as the white race exists, all movements against what is called 'racism' will fail. Therefore, our aim is to abolish the white race."); see laN HANEY LOPEZ, WhITE BY LAW (1995) (discussing the social and legal construction of the white race).

170. See Treason, supra note 5, at 84-86.

171. Id. at 86. 
that firms and institutions rely on unthinkingly, even though they exclude blacks and woinen. They put their lives on the line."172

"So the idea is to show total solidarity with us and our cause."

"Yes, even though this means risking one's job and friendships with whites. If the police and courts could not be sure that every person who looks white is loyal to the system, that system would fall. ${ }^{173}$ For then, what would be the point of extending privileges based on race? Whites would reject loyalty to their own race, rejom the human race, and the idea of the white race would fall of its own weight."

"A radical proposal, Rodrigo," I said. "T'm not sure many of our white friends would adopt it."

"It does entail a radical commitment," Rodrigo conceded. "But, as I mentioned, if only a small proportion of whites did, it would seriously jeopardize the system of white-over-black hegemony that has reigned in this country for over four hundred years. And the form of identification it would generate would be real. As we were discussing earlier, empathy is not particularly reliable. One learns only froin his or her own experience, not that of others. The race traitor role allows people to begin to acquire that experience."

"Could a progressive lawyer, like Alfieri, be a race traitor? Is this a solution to law's confining role?" I asked.

"I'd like to think so," Rodrigo replied. "But I'm skeptical, for all the reasons we just mentioned. Law is structurally biased against empathy. Of course nothing prevents a lawyer from being a race traitor outside his or her work in a law office, nor from using law strategically, from time to time, to advocate the race traitor objective."

"Very interesting, Rodrigo, and it just might work, even if not for lawyers. But I think you said you had a second plan."

\section{B. Rodrigo's Second Plan for Whites: Subversion from Within}

"My second plan sounds almost like the opposite of the first, but as you'll see it's not."

"Please go on. But, by the way, do you need to call Giannina?"

Rodrigo looked at his watcl. "Her worksliop won't be letting out for another forty-five ininutes. Why don't we go on?" (I nodded approval.) "My second plan would envision whites working with whites to lift the yokes of oppression that burden both them and us. I wonder, Professor, if

172. Id. at 85 (describing "six ways to fight being white"); see also John Garvey, Family Matters, 4 RACE TrATroR 23, 26-30 (Winter 1995) (describing opposition to school "gifted program" structured to favor white children).

173. Treason, supra note 5, at 86 ("Our strategy seeks to bring together a determined minority, willing to defy white rules so flagrantly they make it impossible to pretend that all those who look white are loyal to the system of racial oppression."); see When Does the Unreasonable Act Make Sense?, 3 RACE TRATroR 108 (Spring 1994) (editorial). 
you heard the closing speech by the famous white radical at the recent CLS conference." 174

"I did. It was spellbinding, delivered with great panache. He held the entire room, even without a microphone."

"And I'm sure you recall what he said. He described his own upbringmg as a member of the ruling class, as he put it-prep school, Harvard, antiwar rebellions, SDS. He was a creature of the sixties, and when he grew up turned to CLS for inspiration and support."

"He not only turned to CLS, he helped develop it," I interjected. "He was a founding father, helping the new inoveinent carve out such notions as indeterminacy and the theory that law is essentially politics."

"And do you reineinber what he said, Professor, about his own engagement with racial identity groups?"

"I do. He said he had sided with Black Power and the Panthers, although as a more or less distant cheerleader and fellow traveler. He said quite candidly that he thought he had little role beyond that, and that as a member of the white privileged class he could not do inuch more, that there is a sort of built-in limitation. Consequently he turned to institutional politics, the politics of daily life, teaching elite law students how to survive in the corporate world and subvert their own offices and institutions. That and deconstructing legal doctrine.

"What's wrong with that?" I asked, my voice rising slightly. "I was there when he said it, and thought at the time that he was being coininendably honest. What else could someone like him have done in life?"

"I don't want to seem harsh," Rodrigo said quietly. "He's a famous figure, one from whom all of us have learned much."

"But you feel there is more he could have done?"

"Yes. I keep thinking that someone with his charisma and prodigious talent could have done more. All it would have taken would have been a slight shift-a few degrees this way, rather than that."

"And that shift is ...," I cajoled.

"I think our famous friend should have devoted himself, at least in part, to working with his own race, that is, with disaffected working-class whites. He could have supplied them with the analyses and leadership that they needed, and at a crucial time. Working-class, blue-collar whites, ethnic whites, and poor Southern whites today are arrayed against minorities. They have turned against us with a vengeance. They are the 'angry white men' who helped bring about the Republican revolution that is setting back the cause of social and racial justice, challenging affirmative action, and demanding the end of welfare to the poor and desperate."175

174. See Schedule of Events for The Politics of Class and the Construction of Identity: A Crit Network Conference 4 (Mar. 10-12, 1995, on file with author) [hereinafter Crit Network].

175. Without a radical critique, affirmative action simply infuriatcs working-class whites, who correctly perceive that it shifts the cost of racial remedies onto them. See, e.g., Duncan Kennedy, $A$ 
"You are saying that if the famous white radical, and people like him, had stopped flirting with radical chic social movements like the Panthers back in the sixties and gone to preach to their own blue-collar brothers and sisters, we would not be in the fix we are in today?"

"Yes. They might have listened to him. Lower-class whites are not our natural enemies. Quite the contrary. But they think they are. Elite whites neatly use them to deflect attention froin their own crass inaterialisin, inanipulation, and profits-from the way they maintain unsafe workplaces for the workers; pay bare subsistence wages; phase out factories at the drop of a hat, creating real destitution; and send jobs overseas if it suits their interest, all at the expense of workers."176

"So you are saying fancy Crits in elite positions at the top schools aided the Republican revolution and the terrible turn things have taken for our people and for the poor?"

"I am," Rodrigo replied with conviction. "They took the easy way out. Instead of taking their campaign to the factories and lower-class teneinent districts, they listened to the Panthers, shivered a little, and went and wrote elegant law review articles about the structure of Western legal thouglit, mostly for each other's benefit. They abandoned their own people. Empathy-the shallow, chic kind-is always more attractive than responsibility, which is hard work."177

"Is it too late?" I asked.

'It's never too late. Look at what Ralph Nader is doing. He's writing for workers in dangerous factories, consumers who buy unsafe products. ${ }^{178}$ He commumicates effectively. He has a fancy law degree, yet he addresses his message to those who unfortunately have been led to think we are the cause of their economic pain. He's trying to redirect their attention upward, to the corporate elite that is oppressing us all, much as Martin Luther King was preparing to do toward the end of his life, just before he was assassinated. ${ }^{179}$ Robert Kennedy, too. ${ }^{180}$ Workers and middle class whites listen

Cultural Pluralist Case for Affirmative Action in Legal Academia, 1990 Duke L.J. 705. For a proposal that people of color and blue collar whites unite in a coalition to overthrow affirmative action in favor of class solidarity, see Delgado, Tenth Chronicle, supra note 1.

176. Derrick Bell, Property Rights in Whiteness-Their Legal Legacy, Their Economic Costs, in Critical Race Theory: The Cutting Edge 75 (Richard Delgado ed., 1995).

177. On responsibility and evasion, see Jean-Paul Sartre, Beng and Nothingness (Hazel E. Bames trans., Methuen 1957) (1943); see also Alfieri, Reconstructive, supra note 139, (calling for mobilization, radical identification, opposition, and reconstruction as alternatives to currently understood law practice); López, supra note 43, at 329 (same).

178. E.g., Razph Nader, Unsafe at Any Speed: The Designed-in Dangers of the American AutomoBIL (1965).

179. On the Poor People's March and King's planned rapprochement with the poor community, see David J. Garrow, Bearing the Cross: Martin Luther King, JR., and the Southern Christian LEADERSHIP CONFERENCE 575-624 (1986).

180. Toward the end of his life Robert Kennedy demonstrated solidarity with California farm workers, met with leaders of minority and poor communities, and was present at the origin of the Poor People's Campaign. Arthur M. Schilesinger, JR., Robert KenNedy AND His Time 790-91, 846-47, 
to Nader-some of them, at least. There's no reason he should be working at this alone."

"Nader also spoke at the conference you mentioned. He scolded the Crits for devoting their lives to figuring out how many angels can dance on the head of a pin."181

"I missed that session," Rodrigo said. "But I heard it was great. I'm hoping it's on tape. I'd like to see it sometime."

"I think they were taping it," I said. "Maybe your library can get it."

"I'll see when I get home," Rodrigo said. "But, speaking of home, Professor, I think I'd better be moving along soon. Thanks for the company. As usual, you're a great sounding board."

"You've helped me as well. I'd often wondered why empathy for our people, our causes, and for the poor seems to be sharply declining. You've helped me figure out why, and what we might do about it."

"Speaking about doing things, Giannina's workshop ends tomorrow at noon. We were thinking of taking im that new show of early Industrial-era art at that uptown museum. Want to join us? We've got a few free hours before we have to go to the airport."

"I'd love to," I said. "Maybe I'll pick up a postcard at the gift shop and send it to my radical friend you were mentioning. We know each other. Maybe I'll suggest the three of us get together sometime for a small summit conference. What do you think?"

Rodrigo smiled, fished a few bills out of his wallet for his share of the tab, and gave me a quick squeeze on the shoulder. "I'm game," he said. "I kind of like the guy, too. Want to share a cab?"

"You bet. I don't want you self-deconstructing on me again. Ready?"

$872-73,908,914$ (1978). Kennedy was the scion of a wealthy and established family; his willingness to side with oppressed groups and challenge members of his own class gives some indication of the potential for a Race Traitor to shatter ingrained assumptions and work for novel alignments.

181. See Crit Network, supra note 174, at 4. 